\title{
Tectonic controls on residual oil saturation below the present-day fluid contact level in
} reservoirs of the Persian Gulf

\author{
E. Heydari-Farsani ${ }^{1, ~}{ }^{\text {, }}$,. E. Neilson ${ }^{1}$, G. I. Alsop ${ }^{1}$, H. Hamidi ${ }^{2}$ \\ ${ }^{1}$ School of Geosciences, King's College, University of Aberdeen, Aberdeen, AB24 3UE, UK \\ ${ }^{2}$ School of Engineering, King's College, University of Aberdeen, Aberdeen AB24 3UE, UK
}

\begin{abstract}
The presence of residual oil below the present-day free water level (FWL) and oil water contact (OWC) is common in many oil fields in the Middle East, particularly those in the Persian Gulf. This residual oil is seen in both clastic and carbonate reservoirs prior to the start of production. The characterisation and modelling of these fields is difficult in practice. Also, these residual oils below the FWL and OWC could become classified as reserves if ways to produce them could be found. However, the first step is to better understand their origin. Therefore, the goal of this study was to investigate the role of geological events on the presence of the residual oil zone (ROZ) below the FWL and OWC.
\end{abstract}

It has been suggested that the presence of residual oil below the present day FWL and OWC is related to the geotectonic history of the region. From the middle Miocene, reverse faulting and overfolding propagated over the Zagros, leading to the amplification of folds and the migration of the Zagros orogeny towards its foreland basin (Persian Gulf). In response to this additional massive loading on the continental margin, the forebulge amplitude was increased, its location migrated towards the uplifted Zagros Mountains, and consequently the Persian Gulf became narrower. This exerted a north to north-east downward tilting of the entire basin, including all the structures and reservoirs previously filled by hydrocarbons. This basin tilting 
changed the equilibrium of the structures and their fluid contents, and resulted in the hydrocarbons and water attempting to find a new equilibrium. Under these conditions, the early migrated and accumulated oil was flushed out by water (imbibition), and a ROZ was left below the present day FWL and OWCs. The angle of regional basin tilt has been calculated to be $0.836^{\circ}$ based on seismic sections.

Keywords: Residual oil below fluid contact, Zagros collision, Persian Gulf, foreland basin, regional tilting

\section{Introduction}

The Persian Gulf, which is situated at the centre of the Middle East, is the location of remarkable hydrocarbon reservoirs. Many of these reservoirs present a thickness of residual oil below the free water level (FWL) and oil water contact (OWC) prior to the start of production (Figure 1). This residual oil is seen in both carbonate and clastic reservoirs, and in many of them increases towards the northern parts of the fields (Figure 1). Breached and reformed seal, tilted fluid contact due to hydrodynamic aquifer and regional or local basin tilt are the main processes that generate residual oil below the FWL and OWC (Melzer et al., 2006). The characterisation and modelling of reservoirs with residual oil below the FWL and OWC, prior to the start of production, is difficult. Also, these significant reserves of oils occur below the FWL and OWC if ways to produce them can could be found. The first step, however, is to better understand their origin. Therefore, the goal of this study was to improve our understanding of the role of geological events on the presence of residual oil below the FWL and OWC by introducing a new geological model for the Persian Gulf region.

Geological studies have been a fundamental part of exploration and production projects since the beginning of the oil industry in the Persian Gulf. The sedimentology of the Persian Gulf was first studied by Emery (1956), although a better understanding of sediment generation 
processes and the pattern of sediment accumulation was heralded by the publication of The Persian Gulf(Purser, 1973). In addition to these key studies, several others have contributed to our understanding of the geology of the Zagros and its foreland basin (Persian Gulf), including James and Wynd (1965), Mina et al. (1967), Dunnington (1974), Falcon (1974), Setudehnia (1978), Szabo and Kheradpir (1978), Murris (1980), Koop and Stoneley (1982), Beydoun et al. (1992), Motiei (1995), Alsharhan and Nairn (1997), Uchupi et al. (1999), Swift and Ross (2002), Homke et al. (2004), Nadjafi et al. (2004), Vazirimoghaddam et al. (2006) and Khadivi et al. (2010), which have all demonstrated the stratigraphy of different parts of the Zagros and the Persian Gulf. In addition, Ala et al. (1980), Ala (1982), Bordenave and Burwood (1990), Ghasemi-Nejad et al. (2009) and Abdollahifard et al. (2011) specifically studied the petroleum geology of the Zagros and the Persian Gulf.

Alavi and Mahdavi (1994), Ehsanbakhsh (1996), Nazari and Shahidi (1998), KarimiBavandpour (1999), Talebian (1999), Mohajjel and Fergusson (2000) and Alavi (2004) carried out extensive geological mapping in different parts of the Zagros and the Persian Gulf, and have contributed a better understanding of the development of the Zagros Belt and Persian Gulf Basin. The tectonostratigraphy of the Zagros has been studied by Alavi (1996), Sherkati et al. (2006), Mouthereau et al. (2007), Homke et al. (2009, 2010).

Stocklin (1968), Falcon (1974), Colman-Sadd (1978), Bahroudi and Koyi (2003, 2004), McQuarrie (2004), Sherkati and Letouzey (2004), Sepehr and Cosgrove (2004), Molinaro et al. (2005), Lacombe et al. (2006, 2007), Mouthereau et al. (2007), Aubourg et al. (2008) and Jahani et al. (2009) addressed the structural geology of different parts of the Zagros, whilst Vergas et al. (2011) integrated geological and geophysical data to produce a crustal crosssection of the NW Zagros. 
71 The fracture pattern and stress direction in the Zagros have been reported on by Lacombe et al. (2011), and the link between the closure of the Neo-Tethys and the generation of the Zagros has been investigated by Braud and Brunn (1977), Alavi (1980), Berberian and King (1981), Dercourt et al. (1986), Sengör et al. (1988), Dercourt et al. (1993), Alavi (1994), Stampfli and Borel (2002), Agard et al. (2005) and Hafkenscheid et al. (2006).

Tavani et al. (2011) presented deformation pattern of the SW Zagros anticlines. The salt diapirism in the Zagros and adjacent area have been studied by Kent (1958), Falcon (1969), Talbot and Jarvis (1984), Alavi (1994) and Talbot and Alavi (1996).

Faghih and Sarkarinejad (2011) demonstrated ductile deformation in the Sanandaj Sirjan Zone of the Zagros, whilst Allen and Talebian (2011) investigated the fault patterns in the Dezful Embayment, concluding that ophiolite obduction in the Late Cretaceous played an important role in the stratigraphy of the Zagros.

Stöcklin (1968, 1974), Berberian and King (1981), Yilmaz (1993), Alavi (1994), Hooper et al. (1994), Jolivet and Faccenna (2000), Robertson (2000), Fergusson and Sahandi (2003), McQuarrie et al. (2003), Agard et al. (2005), Vincent et al. (2005), Ghasemi and Talbot (2006), Ghalamghash et al. (2009), Mazhari et al. (2009) and Ballato et al. (2010) investigated the time of the collision between the Arabian and Iranian plates, and the position of the collision suture has been demonstrated by Stöcklin (1968), Ricou et al. (1977), Alavi (1994), Agard et al. (2005, 2006), Paul et al. (2006) and Shafaii Moghadam et al. (2010).

Alavi (1996, 1980, 2004, 2007), Koop et al. (1982), Husseini (1989), Talbot and Alavi (1996), Bahroudi and Koyi (2003), Agard et al. (2005, 2011), Sherkati et al. (2006), Homke et al. (2009), Pirouz et al. (2011), Moutherean (2011) and Verdal (2011) analysed the geodynamic evolution of the Zagros through time. 
Studies on residual oil have mostly focused on the remaining and residual oil in the transition zone, not below the FWL or OWC.

Kirkham et al. (1996) suggested that presence of residual oil could be related to the Zagros mountains although didn’t prove it. Mezler et al. (2006) and Koperna et al. (2006) reported significant oil reserves in the residual oil zones (ROZs) of the Permian Basin, USA. The production characteristics of ROZs have been reported on by Parker and Rudd (2000, Middle East reservoirs), Koperna et al. (2006) and Harouaka et al. (2013; Permian Basin reservoirs, USA). Pelissier et. al. (1980) studied the hydrodynamic activity in some of the Middle East reservoirs. Thomasen and Jacobsen (1994) and Vejbaek et al. (2005) evaluated the relationship between active hydrodynamic drive and the presence of ROZs in North Sea reservoirs, and Aleidan at al. (2017) carried out a palaeo-oil characterisation and fundamental analysis of the ROZ for a field in Saudi Arabia.

\section{Field descriptions}

Three fields, located in the east, centre and west of the Persian Gulf, were selected for petrophysical evaluation, and an investigation of the residual oil observed (Figure 1). Due to matters of confidentiality, these fields are referred to throughout as A (east), B (central) and $\mathrm{C}$ (west).

- Field A forms an elongated NNE-SSW anticlinal structure (Figure 1). It is located in the eastern part of an intrashelf basin within the Arabian continental shelf that developed during the middle Cretaceous (Jordan et al., 1985; Alsharhan and Nairn, 1997; Ziegler, 2001). Within this intrashelf basin, the Khatiyah Formation (Fm) facies (end of the Early Cretaceous) was deposited under anoxic conditions, with the organic matter preserved turning the Khatiyah Fm facies into a source rock. This intrashelf 
basin is surrounded by concentric shelf facies belts, including fore-shoal, shoal, back shoal and protected platform facies, corresponding to the Cenomanian-Turonian Sarvak (Mishrif) Fm, which forms the reservoir. The overall progradation of these facies has created a petroleum system in which the carbonate reservoirs of the Sarvak Fm overlie the source rocks of the Khatiyah Fm (Farzadi, 2006). The seal to the Sarvak (Mishrif) reservoir is provided by $2-5 \mathrm{~m}$ of overlying Coniacian Laffan Fm shale (Farzadi, 2006).

- Field B is located in the centre of the Persian Gulf (Figure 1). The field is a gentle domal anticline, trending NNE-SSW, with flanks dipping $1-3^{\circ}$. The oil is produced from three carbonate reservoirs of Late Jurassic to middle Cretaceous age. These reservoirs are the Sarvak (Mishrif) Fm of Cenomanian-Turonian age, the Dariyan (Shuaiba) Fm of Aptian age and the Surmeh Fm (Arab Members A1 and C) of Kimmeridgian-Tithonian age. The carbonate Sarvak (Mishrif) Fm of this field was selected to be incorporated in the study. The seal to the Sarvak (Mishrif) Fm is provided by 20-30 m of overlying Coniacian Laffan Fm shale (Farzadi, 2006).

- Field C is located in the NW Persian Gulf (Figure 1). The structure is an elongated NNE-SSW anticline. The oil is produced from three carbonate and one sandstone reservoirs. The carbonate reservoirs include the Dariyan (Shuaiba) Fm of Aptian age, the Gadvan (Kharaib) Fm of Barremian to Aptian age and the Fahlyian (Yamama) Fm of Berriasian-Valanginian age. The clastic reservoir that was selected to be incorporated in this study is the Albian Sand B of the Kazddumi (Burgan) Fm, which was deposited in a deltaic environment. This reservoir was selected to make sure the ROZ was studied in both carbonate and clastic reservoirs. The seal to the reservoir is provided by almost $50 \mathrm{~m}$ of overlying Kazhdumi shale.

\section{Available data}


- Petrophysical and reservoir data: These data were mainly used to generate computer processing interpretation (CPI) logs to determine the OWC depth, the water and oil saturation and to confirm the presence of the residual oil below the FWL and OWC. A large set of wireline and logging while drilling logs (GR, NPHI, RHOB, DT, SP, RXO and RT) were available, although no nuclear magnetic resonance data exist for these fields. All available logs were inspected and quality checked to make sure only valid data were used. Petrophysical interpretations were carried out on more than 90 wells, using final quality checked logs, conventional core analysis and special core analysis.

- Formation pressure data for before the start of production were available for a limited number of wells for Fields A and C. These were used to define the FWL depth. There is only one well in fields $\mathrm{A}$ and $\mathrm{C}$ with pressure data in the aquifer.

- Drill stem tests (DSTs), core oil-staining and mud-logging gas chromatography (methane, ethane, propane and total gas) were used in conjunction with the CPIs to define the depth of the OWC and to investigate whether residual oil was present below the present-day contact.

- Geological data and studies: A comprehensive literature review was carried out, and the stratigraphy, tectonics, depositional environment and petroleum geology were analysed and integrated with the petrophysical results to present a model for the presence of residual oil below the FWL and OWC. A summary of this study is presented in Section 5.

- Geophysical data: Seismic lines were used to investigate and calculate the subsidence, tilting and flexural loading of the Persian Gulf Basin. 
The FWL is the level at which the capillary pressure (pressure of the non-wetting phase pressure of the wetting phase) is zero (Spinler and Baldwin, 1999; Darling, 2005; Tiab and Donaldson, 2015). In theory, it is a potentiometric surface, best determined using pressure data to define the intersection between the hydrocarbon zone gradient and the water zone gradient on a formation pressure vs. depth crossplot (Tiab and Donaldson, 2015). Above the FWL, where the capillary pressure is not zero, hydrocarbons can displace water.

The OWC is the point at which the water saturation (Sw) is $100 \%$ (in theory), and the capillary pressure is not zero (Spinler and Baldwin, 1999; Darling, 2005; Tiab and Donaldson, 2015). The OWC is apparent on well logs, in cores (by oil-staining) and in mudlogging gas data (Tiab and Donaldson, 2015). At the OWC, the hydrocarbon saturation starts to increase upwards from some minimum (Elshahawi et al., 1999).

In rocks with poor reservoir quality (small pore throat size and low permeability), a certain entry pressure is required before the value of $\mathrm{Sw}$ can fall below unity. Once this pressure is reached, hydrocarbons will be found in the rock (Darling, 2005).

In reservoirs with good reservoir quality (i.e. all reservoirs in the studied fields with an average permeability of 10-200 mD), the FWL and OWC occur at close depths (Darling, 2005; Tiab and Donaldson, 2015). In this study therefore, 'fluid contact' is used as a general term to describe where the FWL and OWC cannot be resolved or have a similar depth. The FWL, OWC, oil down to (ODT) and water up to (WUT) were defined for more than 90 wells in the studied fields, with special attention being paid to the early wells that were drilled prior to the start of production. 
Field A has a FWL at $2900 \mathrm{~m}$ TVDSS, obtained from the formation pressure data (Figure 2A). There are also three preproduction wells located in the north and south of the field that display OWCs (determined mainly from log data) with almost similar depths (Figure 3A). The northernmost well (A4) in this field has a WUT at $2912 \mathrm{~m}$ TVDSS.

Field B has an OWC at $1221 \mathrm{~m}$ TVDSS, based on data from five wells located in different parts of the field. There is no formation pressure data for this field (Figure 3B).

Field C illustrates a FWL at 2337 m TVDSS, determined by extrapolation of the formation pressure data (Figure 2B) from a well located in the south of the field (Figure 3C). The depth of this FWL is supported by the ODT and WUT seen in a well drilled on the northern flank of the field (Figure 3C). The ODT is apparent above a shaley interval at $2334 \mathrm{~m}$ TVDSS, and the WUT is located $10 \mathrm{~m}$ deeper, at $2343 \mathrm{~m}$ TVDSS (Figure 3C). Therefore, the OWC depth in the northern flank is located between 2334 and 2343 m TVDSS, very close to the FWL depth seen in the southern parts of the field.

Based on the petrophysical interpretation and fluid contact determination performed in the studied fields, the following significant observations were made:

1- The present-day FWL and OWC in these fields do not correspond to $100 \% \mathrm{Sw}$, but to $50-60 \%$ Sw in some areas of Field A, $80 \% \mathrm{Sw}$ in some areas of Field B and $75 \% \mathrm{Sw}$ in some areas of Field C (Figures 3). This indicates that there is a ROZ below the present-day FWL and OWC in all three fields.

2- The presence of residual oil below the present-day FWL and OWC is predominantly seen in the northern parts of the fields, rather than the southern parts (Figures 1, 3), regardless of lithology.

3- No tilting of the fluid contact was observed in the early wells in the studied fields 
(Figure 3). The FWL and OWCs depths show minimum deviation across Fields A and C. A similar observation was made for Field B using the OWC depths in the early wells.

\section{Regional geology}

The regional geology of the Persian Gulf and surrounding area was investigated to explore the possible effect of geological events on the natural water flooding and presence of residual oil below the FWL and OWC. Special attention was paid to basin analysis and its relationship to oil generation in the source rock, its migration to the reservoir, the structural history and possible further changes in the fluid equilibrium. A summary of regional geology and main events are shown in Figure 4.

The Persian Gulf is part of the Arabian continental plate. The petroleum geology of the Arabian Plate has been controlled by the various tectonic activities; in the Persian Gulf, the Zagros collision has played the major role.

The Zagros Fold-thrust Belt has been defined as a NW-SE-trending orogeny, extending for about $1800 \mathrm{~km}$ from the East Anatolian Fault in eastern Turkey $\left(45^{\circ} \mathrm{E}, 36^{\circ} \mathrm{E}\right)$ to the Makran Subduction Zone in southern Iran $\left(26^{\circ} \mathrm{N}, 58^{\circ} \mathrm{E}\right)$ (Mouthereau et al., 2012).

The sediments drilled by the wells and evident in outcrops show the evolution of $10 \mathrm{~km}$ of deposits, from the passive margin to the active margin and foreland basin in the Zagros and the Persian Gulf Basin (Morris, 1977).

\subsection{Passive margin}

During the Late Permian to Middle Triassic, a new passive margin developed after the opening of the Neo-Tethys Ocean (Ziegler, 2001). The sediments of this passive margin 
deposited in an equatorial shallow-platform sea. This passive margin continued until the end of the Mesozoic, and its sediments form $5 \mathrm{~km}$ of alternating carbonate, siliciclastic and evaporitic deposits (Homke et al., 2004; Sherkati and Letouzey, 2004; Farzipour-Saein et al., 2009). The majority of the source rock and hydrocarbon reservoir formations of the Middle East were deposited in this passive margin, including the Khatiyah (source rock in Fields A and B), Sarvak (reservoir in Fields A and B) and Kazhdumi (source rock and reservoir in Field C) Fms in the studied fields.

\subsection{Generation of the foreland basin}

Many of the anticlinal structural traps in the Persian Gulf (including those of Fields A-C) were the result of doming of the underlying Cambrian Hormuz salt prior to the Turonian and the deposition of the Sarvak (Mishrif) and Kazhdumi Fms (Arian and Noroozpour, 2015).

Following the generation of the anticlinal structures, the Neo-Tethys Ocean continued to close due to the continuous subduction of the Afro-Arabian Plate beneath the Eurasian Plate (Alavi, 2004; Mouthereau et al., 2012). As a result of this subduction, in the Eocene (between 55 and $37 \mathrm{Ma}$ ), a magmatic flare-up occurred in the Uromieh Dokhtar Magmatic Arc (Vincent at al., 2005; Agard et al., 2011; Verdel et al., 2011). Magmatism in the UDMA ceased before the start of collision in various parts of the Zagros in the Oligo-Miocene (Chung et al., 2010 in Agard et al., 2011). Campanian/Early Maastrichtian, oceanic sedimentary prisms and ophiolite masses were overthrust and glided onto the edge of the Arabian shelf from NW Syria to SE Oman

254 (Beydoun et al., 1992). 
The crustal thickening associated with the tectonic evolution in the NE of the Persian Gulf caused the lithosphere to bend, resulting in the development of a foreland basin (foredeep) and its associated forebulge to the south and SW of the Zagros. This foreland basin is about $2000 \mathrm{~km}$ in length (Hail-Gaara Arch to Zendan-Minab Fault Zone) and some 250 to $350 \mathrm{~km}$ in width. It includes the terrestrial Mesapotamia Basin in Iraq and the Persian Gulf (Figure 1).

Foreland basins are the elongated sedimentary basins located on continental lithosphere at the outer edges of mountain belts (Dickinson, 1974). The distal margin of a foreland basin is defined by the forebulge, which is a small uplift, formed by the strength and resistance of the lithosphere in reaction to the loading caused by folding and thrusting (Dickson, 1974 and Miall, 2010). There is evidence that the forebulge can migrate across a foreland basin, both towards and away from the thrust and fold belt, and that it may, in some cases, act as a localised sediment source (DeCelles and Giles, 1996).

While emplacement of the Neo-Tethyan ophiolites onto the Afro-Arabian Plate was ongoing during the Campanian-Early Maastrichtian (Alavi, 2004), in the Zagros and Persian Gulf area, deposition of the Ilam and Gurpi Fms occurred (Figure 5). In the northern part of the Persian Gulf, closer to the Zagros front, sandstones and conglomerates of the Amiran Fm are present, which were sourced from the erosion of ophiolite wedges (James and Wynd, 1965; Mouthereau et al., 2012).

During the Eocene, the Kashgan, Shahbazan, Pabdeh and Jahrum Fms were deposited in the Persian Gulf foreland basin (Figure 5), while continued thrust stacking and ophiolite emplacement were the major events of the progressive deformation (Alavi, 2004). This period of deposition was followed by a hiatus in sedimentation in the area. This may have been the result of uplift of the Arabian continental margin, following the sedimentation of the 
278 Kashkan, Shahbazan, Pabdeh and Jahrum Fms, but prior to a marine transgression and deposition of the Asmari Fm.

\subsection{Hydrocarbon generation and the filling of structures}

281

The crustal thickening associated with the tectonic evolution of the Zagros provided a huge sediment supply to the basin. As a result of this massive sediment supply and the increasing burial of older formations, the Kazhdumi (Middle Albian) and Khatiyah (Upper Albian) Fms, which are the source rocks of the studied fields, entered the oil window in the Eocene around $39 \mathrm{Ma}$, during deposition of the Pabdeh Fm. Oil generation continued, and then the oil migrated to the reservoirs. The fluid connection between the source rock and the reservoir was facilitated by faults and fractures (Bordenave, 2002). Based on geochemical and burial history studies, the oil migration was complete by the Late Eocene/Early Oligocene. At this time, it is assumed that the structures were completely filled with oil, from the crest to the fluid contact or spill point.

\subsection{Collision and Persian Gulf Basin tilting}

Figure 5 shows the sedimentation of different formations in the Persian Gulf foreland basin, from the Turonian to the Miocene. The location of one of the studied fields (B) is also shown.

The Zagros collision was initiated in the Late Eocene-Early Oligocene (Mouthereau et al., 2012). However, the elevation, uplift and exposure of older sediments started later, in the Miocene (Emami, 2008; Khadivi et al., 2012; Mouthereau et al., 2012). At 15 Ma, folding began in the northern parts of the Zagros, and then propagated southwards after 12 to $11 \mathrm{Ma}$ (Emami, 2008; Khadivi et al., 2012). Numerous thrust faults and folds were generated in an area around $300 \mathrm{~km}$ wide. As a result of this deformation, a shortening of 40 to $70 \mathrm{~km}$ occurred in the Zagros area (Sherkati and Letouzey, 2004; Molinaro et al., 2005). This crustal shortening and thickening resulted in the uplift of the Zagros region. 
The Early Miocene witnessed a significant change in the direction of plate motion, from NE to north. This occurred following rifting in the Red Sea (McQuarrie et al., 2003; Arrajehi et al., 2010) and the westward opening of the Gulf of Aden (Leroy, 2004).

From the Middle Miocene, the Zagros Mountains developed their present shape, reaching a height of more than $4548 \mathrm{~m}$. Reverse faulting and overfolding propagated over the Zagros, reaching the foreland basin, and leading to the amplification of folds and the migration of the Zagros Orogeny towards its foreland basin.

In response to this additional massive loading on the continental margin, the forebulge amplitude increased, and its location moved towards the uplifted Zagros (Alavi, 2004) (Figure 6). As a result of this forebulge movement, the Persian Gulf foreland basin migrated towards the orogenic suture (Alavi, 2004), becoming narrower (Figure 6). This would have exerted a north to NE downward tilt of the entire basin, including all the structures and reservoirs filled by hydrocarbons, from the crest to the fluid contact or spill point. The location of Field B, before and after the tectonic subsidence, is shown with dashed and solid rectangles, respectively, in Figure 6.

The erosion of the uplifted rocks may have generated sufficient sediments for the deposition of the 3000-m-thick regressive siliciclastic sequence of the Razak, Guri, Gachsaran, Mishan, Aghajari and Bakhtiyari Fms in different parts of this narrower compressional basin (Figure 7). These sediments display distinctive lateral and vertical facies variations, and were affected by various tectonic events. The younger formations comprise coarsening-upward flysch and molasse sequences, and display a continuation of the progradation of sediments sourced from the Zagros towards the SW through time.

\section{Discussion of residual oil below present-day fluid contacts}


Prior to the start of reservoir production, residual oil below the FWL and OWC generally occurs because of the natural and geological water flooding of an oil reservoir (O'Sullivan et al., 2010; Aliedan et al., 2016). The main processes that generate ROZs below fluid contacts are (Melzer et al., 2006):

- Breaching and reforming of the seal;

- Tilted fluid contact due to hydrodynamic aquifer; and

- Regional or local basin tilt.

Breaching and reforming of the seal. Breaching of the seal occurs as a result of tectonic forces or due to the hydrocarbon column height being sufficient to break the seal (O'Sullivan et al., 2010). In this case, hydrocarbons partially escape from the reservoir and, if the new oil column is significantly less than the original one, a thickness of residual oil will occur below the remaining oil as basinal water moves up into the oil-depleted interval (Figure 8A). If seal failure happens, a constant thickness of the ROZ is seen below the remaining oil across the entire field (Figure 8A).

As mentioned earlier, residual oil below the present-day fluid contact is not uniformly found across all the studied fields; it is mainly seen in the northern parts of the studied fields (Figures 1 and 3). This option for the presence of the residual oil below the present-day fluid contact in these fields can therefore be discounted.

Tilted fluid contact due to hydrodynamic aquifer. A change in the hydrodynamic conditions in the aquifers of oil reservoirs (or active hydrodynamic conditions) is another reason for the occurrence of ROZs below the fluid contact. This happens when the aquifer formation crops out at the surface, where water can gain access and consequently changes the discharge pressure (Figure 8B). This results in a tilted present-day OWC, dipping in the downstream direction (Melzer et al., 2006). The degree of fluid contact tilt is controlled by 
the rate of water movement in the aquifer, and the density difference between the oil and the water. An increase in the hydrodynamic forces results in forced imbibition, and replacement of the oil by water (Figure 8B). As forced imbibition leads to negative capillary pressure, the residual oil saturation in this type of ROZ is lower than in the other two types of ROZ (breached seal and tectonic tilt).

Although tilted OWCs resulting from hydrodynamic flow have been reported in a few fields in the Middle East (Pelissier et al., 1980), evidence for this was not observed in any of the studied fields. All of the studied fields show relatively horizontal present-day fluid contacts (see fluid contact determination and Figure 3).

Also, in the Persian Gulf, the angle of tilt due to possible hydrodynamic activity is towards the west/NW (Pelissier et al., 1980). If aquifer drive caused the ROZs, they would be seen in the eastern and SE parts of the studied fields, and not in the northern parts. Furthermore, no meaningful salinity variation in the aquifer (below FWL and OWC) has been observed, from north to south or east to west in each field. Therefore, it is unlikely that hydrodynamic aquifer generated the ROZs below the fluid contacts in the studied fields.

Regional or local basin tilt. ROZs below fluid contacts can be generated by regional tectonic tilting and oil remobilisation (Figure 8C). Residual oil is left behind because of the buoyancy of oil. Oil is displaced by the spontaneous imbibition of formation waters into the reservoir as the oil evacuates upwards. These reservoirs with ROZ normally constitute significant intervals of residual oil if the size of the field and/or basin tilting is considerable (Melzer et al., 2006). Fields with ROZs below the fluid contact because of tectonic tilting show flat present-day fluid contacts (Figure 8C). They also show ROZs below the fluid contact and towards the down-dip direction (Figure 8C). This tilting process of ROZ 
generation below the present-day FWL and OWC towards the NE matches the pattern of geological events in the Persian Gulf towards the Zagros.

Consequently, it was concluded that the additional flexural loading and north to NE downwards tectonic tilting after the Miocene (Figure 6) could explain the presence of the ROZ below the present day FWL and OWC in the studied fields in the Persian Gulf better than the other processes described.

The presence of residual oil below the present-day fluid contacts is due to a change in the fluid contact position caused by tectonic basin tilting, and consequent structural tilting, millions of years after the generation of the oil and its migration into the reservoirs. This structural tilting has played a consequential role in the equilibrium of the reservoirs and their fluid contents. Following this, the hydrocarbons and water attempted to achieve a new equilibrium. Under these conditions, early migrated and accumulated oil was flushed out by water (imbibition), and a ROZ was left below the present-day FWL and OWCs.

Figure 9A shows N/NE to S/SW cross-sections through Field A, before and after the Middle Miocene. Five different areas (1-5) are defined. As oil was generated in the source rock at around $39 \mathrm{Ma}$, and then migrated into the reservoir formation some $26 \mathrm{Ma}$ (at the beginning of the Lower Fars deposition), it is suggested that the reservoir structure was filled with oil from the crest downwards, with the final stage represented by the palaeo-OWC. Therefore, Regions 1 and 5 were located below the fluid contact, and Regions 2, 3 and 4 were above the contact, after the time of oil filling. At this time, the oil saturation profile above the fluid contact is represented by drainage capillary pressure curves (Adams, 2016).

From the Middle Miocene to the present, additional flexural loading and north to NE downwards tectonic tilting caused the intervals located in Regions 2 and 4 to move below the 
depths of the FWL and OWC (Figure 9B). Water once again penetrated the pore spaces in parts of Regions 2 and 4, and some (but not all) of the early accumulated oil was displaced by water. Subsequent to this fluid movement, residual oil was established below the new FWL and OWC depths in Regions 2 and 4, not only because the water was no longer the only wetting phase (McPhee et al., 2015), but also because not all of the oil was flushed out, with a percentage of it being trapped in some of the pores. The hydrocarbon saturation profile at this stage is represented by imbibition capillary pressure curves (Adams, 2016).

Based on the suggested model, all of the reservoirs filled by migrated oil before the Miocene should present both palaeo and present-day fluid contacts in the northern wells drilled beyond the present-day reservoir boundary. There is a delineation well that was drilled on the northern flank of Field A (A4) and penetrates reservoir formation beyond the determined FWL and OWC. This well presents a palaeo-OWC that is $42 \mathrm{~m}$ deeper than the present-day FWL and OWC.

As mentioned in fluid contact determination, Field A exhibits a FWL at 2900 m TVDSS in Well A6, drilled in the northern part of this field. This FWL is confirmed by the same OWC depth, determined in other wells. The A6 appraisal well was drilled to locate the FWL and OWC in the northern part of the field, and to determine the thickness of the reservoir and assess the characteristics and the productivity of the reservoir. Well A6 has petrophysical logs, mud-logging gas data, core data, formation pressure data and DSTs. Analysis of these data, particularly the formation pressure data, leads to a FWL at $2900 \mathrm{~m}$ TVDSS (Figures 2A and 10). In the same well, the results of the petrophysical evaluation indicated a significant percentage of residual oil below 2900 m TVDSS (Figure 10, track 8), where the residual oil saturation (ROS) was computed to be in the range of 50\%. In addition, the core data shows oil-staining below $2900 \mathrm{~m}$ TVDSS (Figure 10, track 10). 
Well A4 was drilled $3000 \mathrm{~m}$ from Well A6 to locate the northern limit of Field A (Figure 9).

This well has a set of data that includes petrophysical logs, a DST, mud-logging gas chromatography and core data. The top of the Sarvak (Mishrif) reservoir is seen at $2912 \mathrm{~m}$ TVDSS in Well A4 (Figure 11), which is $12 \mathrm{~m}$ below the FWL determined by pressure data in nearby Well A6 (Figures 2A and 10). In Well A4, the upper part of the Sarvak (Mishrif) Fm does not correspond to $100 \% \mathrm{Sw}$, as would be expected below the FWL, but only to $70 \%$, which equates to a $30 \%$ oil saturation (Figure 11, tracks 7, 8). The available DST data (2922 to $2965 \mathrm{~m}$ TVDSS) shows that this oil is residual oil that has been left behind, and is not movable. The presence of residual oil was also confirmed by core oil-staining. At the bottom of the ROZ, the Sw increases to $100 \%$ on the CPI (Figure 11), without any oil-staining or fluorescence on the cores, suggesting the presence of a palaeo-OWC at $2942 \mathrm{~m}$ TVDSS (42 $m$ deeper than the present-day FWL and OWC). This is the position of the fluid contact of Field A in the Sarvak (Mishrif) Fm, before northwards tilting from the extra loading and forebulge movement towards the Zagros that occurred after the Middle Miocene.

The flexural loading is clear on $\mathrm{N}-\mathrm{S}$ regional seismic lines from the Persian Gulf. Figure 12A shows a 140-km-long seismic line, near to Field C. This seismic line shows the asymmetric and wedge-shaped Persian Gulf. Major variations in sediment thicknesses, from south to north, began after the Middle Miocene. The Middle Miocene horizon shows a $2050 \mathrm{~m}$ flexural load over $140 \mathrm{~km}$, suggesting a tilt of $0.836^{\circ}$ for the Persian Gulf foreland basin. Figure 12B shows a NE-SW acoustic impedance section through Field B that emphasises a similar northward tilting.

Where no proper seismic section was available (e.g. Field A), a comparison of formation thickness and structural growth was used to explore the effect of tilting on formation thickness and sedimentation. Several cross-sections, each based on three wells, were prepared 
across the field. Variations in formation thickness were calculated by subtracting the

444 formation thickness in the crestal well (A2) from those in the flank wells (A4, A5, A6, A38).

Figure 13 shows the results from Field A, illustrating how formation thicknesses vary across the field through time, relative to those at the crest of the structure.

447 Figure 13 A and B show that structuration was effective at the end of Mishrif deposition. Thicker deposits of up to 80m of Sarvak (Mishriff) Fm accumulated around the flanks of the 449 structure and is very clear on plots.

By the time of deposition of the Pabdeh Fm in the Eocene, a change in depositional patterns

451 had occurred. In the northern and north eastern wells of field (A4, A5 and A6), thinner 452 deposits are observed compared to the southern well, A38. This indicates less 453 accommodation space to the north and east of the structure during this time and a greater 454 sediment supply from the south.

Both cross sections illustrate an increase in the thickness of the formations deposited since the Miocene (Guri, Gachsaran, Mishan, Aghajari and Bakhtiyari Fms) in the northern wells (A4 and A6) compared to the central (A2) and southern wells (A5 and A38). This suggests that more accommodation space began to be generated to the north of Field A after the Middle Miocene. More accommodation space was provided by additional tilting towards the north and NW, which was superimposed on the entire basin.

\section{Conclusions}

462 The results of extensive regional studies were integrated with the data from three selected fields in the Persian Gulf to present a geological model that would explain the presence of residual oil below the present-day FWL and OWC in the area. 
It was concluded that the presence of residual oil below the present-day FWL and OWC is related to the geotectonic and plate margin evolution of the region, particularly the convergence and collision of the Afro-Arabian and Eurasian Plates. In these fields, the residual oil below the present-day FWL and OWC can be best explained by a change in the fluid contact position caused by extra flexural loading and northwards tectonic tilting that occurred millions of years after the generation and migration of the oil into the structures.

471 From the Late Turonian, the crustal thickening associated with the tectonic evolution caused

472 the lithosphere to bend, resulting in the development of a foreland basin and its forebulge to 473 the south and SW of the Zagros. The Zagros foreland basin includes the terrestrial Mesapotamia and Persian Gulf Basins.

The crustal thickening associated with the tectonic evolution in the area creating the Zagros provided a huge sediment supply to the foreland basin. As a result of this massive sediment supply, and the increasing burial of older formations, the source rocks entered the oil window around the Eocene. The generated oil migrated into the reservoirs through faults and fractures before the Miocene.

From the Miocene onwards, reverse faulting and overfolding developed across the Zagros, extending to the foreland basin, and leading to extra faulting, folding and migration of the Zagros Orogeny towards its foreland basin (Persian Gulf).

The Zagros Mountains developed their present configuration before the end of the Neogene. In response to this additional huge loading on the continental margin, the forebulge amplitude increased, and its location moved towards the uplifted Zagros, and consequently the Persian 
487

488

489

490

491

492

493

494

495

496

497

498

499

500

501

502

503

504

505

506

507

including all structures and reservoirs filled by hydrocarbons, from the crest to the fluid contact or spill point.

Tectonic tilting changed the position of the fluid contacts in these fields, and therefore the equilibrium of the reservoir fluid contents. Following this, the hydrocarbons and water attempted to achieve a new equilibrium. Water once again penetrated the pore space in parts of the reservoirs (located above the older contact, but below the new fluid contact), and early accumulated oil was displaced by water. Subsequent to this fluid movement, residual oil was established below the new contact, not only because the water was no longer the only wetting phase, but also because not all of the oil was flushed out, a percentage of it being trapped. The hydrocarbon saturation profile at this stage is represented by imbibition capillary pressure curves.

The tilting angle of the foreland basin (Persian Gulf) was calculated to be around $0.836^{\circ}$.

\section{Acknowledgments}

The authors would like to acknowledge, and gratefully appreciate the support of, the Aberdeen Formation Evaluation Society for their sponsorship, and Emerson (Paradigm) for providing the Geolog software for the development of this study.

\section{References}

Abdollahie Fard, I., Sepehr, M., Sherkati, S., 2011. Neogene salt in SW Iran and its interaction with Zagros folding. Geological Magazine 148, 854-867.

Adams, S., 2016. Saturation-Height Modelling for Reservoir Description. The Petrophysicist Limited. ISBN: 9780473355197. 
508 Agard, P., Omrani, J., Jolivet, L., Mouthereau, F., 2005. Convergence history across Zagros 509 (Iran): Constraints from collisional and earlier deformation. International Journal of Earth 510 Sciences (Geologische Rundschau) 94, 401-419.

511 Agard, P., Omrani, J., Jolivet, L., Whitechurch, H., Vriielynck, B., Sparkman, W., Monie, P., 512 Meyer, B., Wortel, R., 2011. Zagros orogeny: A subduction-dominated process. Geological 513 Magazine 148, 692-725.

514 Ala, M. A., 1982. Chronology of trap formation and migration of hydrocarbons in the Zagros 515 sector of southwest Iran. AAPG Bulletin 66, 1535-1541.

516 Ala, M. A., Kinghorn, R. R. F., Rahman, M., 1980. Organic geochemistry and source rock 517 characteristics of the Zagros petroleum province, southwest Iran. Journal of Petroleum 518 Geology 3, 61-89.

519 Alavi, M., 1980. Tectonostratigraphic evolution of the Zagrosides of Iran. Geology 8, 144520149.

521 Alavi, M., 1994. Tectonics of the Zagros orogenic belt of Iran: New data and interpretations. 522 Tectonophysics 229, 211-238.

523 Alavi, M., 1996. Tectonostratigraphic synthesis and structural style of the Alborz mountain 524 system in northern Iran. Journal of Geodynamics 21, 1-33.

525 Alavi, M., 2004. Regional stratigraphy of the Zagros fold thrust belt of Iran and its 526 proforeland evolution. American Journal of Science 304, 1-20.

527 Alavi, M., Mahdavi, M. A., 1994. Stratigraphy and structures of the Nahavand region in 528 western Iran and their implications for the Zagros tectonics. Geological Magazine 131, 43-47. 
529 Aleidan, A., Kwak, H., Muller, H., Zhou, X., 2017. Residual-Oil Zone: Paleo-Oil

530 Characterization and Fundamental Analysis. Society of Petroleum Engineers, 260-268.

531 Ali, M., Watts, A. B., 2009. Subsidence history, gravity anomalies and flexure of the United

532 Arab Emirates (UAE) foreland basin. GeoArabia 14(2), 17-44.

533 Allen, M., Talebian, M., 2011. Structural variation along the Zagros and the nature of the

534 Dezful Embayment. Geological Magazine 148(5-6), 911-924.

535 doi:10.1017/S0016756811000318

536 Alsharhan, A. S., Nairn, A. E. M., 1997. Sedimentary Basins and Petroleum Geology of the 537 Middle East. Elsevier Science Publishing: Netherlands.

538 Arian, M., Noroozpoor, H., 2015. Tectonic Geomorphology of Iran's Salt Structures. Open 539 Journal of Geology 5, 61-72.

540 Arrajehi, A., Mcclusky, S., Reilinger, R., Daoud, M., Alchalbi, A., Ergintav, S., Gomez, F., 541 Sholan, J., Bou-Rabee, F., Ogubazghi, G., Haileab, B., Fisseha, S., Asfaw, L., Mahmoud, S., 542 Rayan, A., Bendik, R., Kogan, L., 2010. Geodetic constraints on the present-day motion of 543 the Arabian Plate: Implications for Red Sea and Gulf of Aden rifting. Tectonics 29, 544 https://doi.org/10.1029/2009TC002482.

545 Bahroudi, A., Koyi, H. A., 2003. Effect of the spatial distribution of Hormuz salt on 546 deformation style in the Zagros fold and thrust belt: An analogue modelling approach. 547 Journal of the Geological Society, London 160, 719-733.

548 Bahroudi, A. and Koyi, H. A., 2004. Tectono-sedimentary framework of the Gachsaran 549 Formation in the Zagros foreland basin. Marine and Petroleum Geology 21, 1295-1310. 
550 Berberian, F., Muir, I. D., Pankhurst, R. J., Berberian, M., 1982. Late Cretaceous and early

551 Miocene Andean type plutonic activity in northern Makran and Central Iran. Journal of

552 Geological Society, London 139, 605-614.

553 Berberian, M., King, G. C. P., 1981. Towards a paleogeography and tectonic evolution of 554 Iran. Canadian Journal of Earth Sciences 18, 1764-1766.

555 Beydoun, Z. R., Hughes, M. W., Stoneley, R., 1992. Petroleum in the Zagros basin: A late 556 Tertiary foreland basin overprinted onto the outer edge of the vast hydrocarbon-rich 557 Paleozoic-Mesozoic passive margin shelf. AAPG Memoir 55, 307-336.

558 Bordenave, M. L., 2002. Gas prospective areas in the Zagros domain of Iran and the gulf 559 Iranian waters. AAPG Annual meeting, March 10-13, Houston, Texas.

560 Carpentier, B., Arab, H., Pluchery, E., Chautrau, J., 2006. Tar mats and residual oil 561 distribution in a giant oil field offshore Abu Dhabi. Journal of Petroleum Science and 562 Engineering 58, 472-490.

563 Chung, S. L., Zarrinkoub, M. H., Karakhanyan, A. S., Javakhishvili, Z.,Lo, C. H., 2010. A 564 comparative study of the Tibet/Himalaya and Caucasus/Iran orogenic belts: Magmatic per565 spectives, tectonic crossroads: Evolving orogens of Eurasia-Africa-Arabia. GSA: Ankara, 566 Turkey.

567 Colman-Sadd, S., 1978. Fold development in the Zagros simply folded belt, Southwest Iran. 568 AAPG Bulletin 62, 984-1003.

569 Darling, T., 2005. Well Logging and Formation Evaluation. Gulf Professional Publishing: $570 \quad$ ISBN 9780750678834

571 Decelles, P. G., Giles, K. A., 1996. Foreland basin systems. Basin Research 8, 105-123. 
572 Dercourt, J., Ricou, L. E., Vrielynck, B., 1993. Atlas of Tethys Palaeoenvironmental maps. 573 Gauthier-Villars: Paris

574 Dercourt, J., Zonenshain, L. P., Ricou, L.-E., Kazmin, V. G., Le pichon, X., Knipper, A. L., 575 Grandjacquet, C., Sbortshikov, I. M., Geyssant, J., Lepvrier, C., Pechersky, D. H., Boulin, J., 576 Sibuet, J.-C., Savostin, L. A., Sorokhtin, O., Westphal, M., Bazhenov, M. L., Lauer, J. P., 577 Biju-Duval, B., 1986. Geological evolution of the Tethys belt from the Atlantic to the Pamirs 578 since the Lias. Tectonophysics 123, 241-315.

579 Dickson, W. R., 1974. Plate tectonics and sedimentation. Special Publication of the SEPM 580 22, 1-27. doi:10.1029/2005JB003791

581 Elshahawi, H., Fathy, K., Hiekal, S., 1999. Capillary Pressure and Rock Wettability Effects 582 on Wireline Formation Tester Measurements. Society of Petroleum Engineers. 583 doi:10.2118/56712-MS

584 Emami, H., 2008. Foreland propagation of folding and structure of the Mountain Front 585 Flexure in the Pusht-e Kuh Arc (NW Zagros, Iran). PhD thesis, University of Barcelona, pp. $586 \quad 1-181$.

587 Emery, K. O., 1956. Sediments and water of the Persian Gulf. Bulletin of the AAPG 40, $588 \quad 2354-2383$.

589 Faghih, A., Sarkarinejad, K., 2011, Kinematics of rock flow and fabric development 590 associated with shear deformation within the Zagros transpression zone, Iran. Geological 591 Magazine 148, 1009-1017. 
592

593

594

595

596

597

598

599

600

601

602

603

604

605

606

607

608

609

610

611

612

Falcon, N. L., 1969. Problems of the relationship between surface structure and deep displacements illustrated by the Zagros range. Geological Society of London, Special Publication 5, 9-22.

Falcon, N. L., 1974. An outline of the geology of the Iranian Makran. Geographical Journal 140, 283-291.

Falcon, N. L., 1974. Southern Iran: Zagros Mountains. Geological Society of London, Special Publication 4, 199-211.

Farzadi, P., 2006. The development of Middle Cretaceous carbonate platforms, Persian Gulf, Iran: Constraints from seismic stratigraphy, wells and biostratigraphy. Petroleum Geoscience $12,59-68$.

Farzipour-Saein, A., Yassaghi, A., Sherkati, S., Koyi, H., 2009. Basin evolution of the Lurestan Region in the Zagros Fold-and-Thrust Belt, Iran. Journal of Petroleum Geology $32(1), 5-20$.

Ghasemi-Nejad, E., Head, M., Naderi, M., 2009. Palynology and petroleum potential of the Khazhdumi Formation (Cretaceous: Albian-Cenomanian) in the South Pars field, northern Persian Gulf. Marine and Petroleum Geology 26, 805-816.

Ghazban, F., Motiei, H., 2010. Petroleum Geology of the Persian Gulf, Iran. National Iranian Oil Company Publications, ISBN 9789640394205

Hafkenscheid, E., Wortel, M. J. R., Spakman, W., 2006. Subduction history of the Tethyanderived seismic tomography and tectonic reconstruction. Journal of Geophysical Research 111, B08401. 
613 Harouaka, A., Trentham, B., Melzer, S., 2013. Long Overlooked Residual Oil Zones (ROZs)

614 Are Brought into the Limelight. Society of Petroleum Engineers, 167209.

615 Homke, S., Verges, J., Garces, M., Emami, H., Karpuz, R., 2004. Magnetostratigraphy of 616 Miocene-Pliocene Zagros foreland deposits in the front of the Push-e Kush Arc (Lurestan 617 Province, Iran). Earth and Planetary Science Letters 225(3-4), 397-410.

Homke, S., Vergés, J., Serra-Kiel, J., Bernaola, G., Sharp, I., Garcés, M., Montero-Verdù, I., 619 Karpuz, R., Goodarzi, M. H., 2009. Late Cretaceous-Paleocene formation of the proto-Zagros foreland basin, Lurestan Province, SW Iran. GSA Bulletin 121, 963-978.

621

Hooper, R. J., Baron, I. R., Agah, S., Hatcher, R. D., 1994. The Cenomanian to Recent

622 development of the southern Tethyan Margin in Iran. In: Al-Husseini, M. I. (ed.), Middle 623 East Petroleum Geosciences, GEO 94(2), pp. 505-516. Gulf PetroLink: Bahrain.

Jahani, S., Callot, J.-P., Letouzey, J., Frizon de Lamotte, D., 2009. The eastern termination of the Zagros Fold-and-Thrust Belt, Iran: Structures, evolution, and relationships between salt 626 plugs, folding, and faulting. Tectonics 28, TC6004. doi:10.1029/2008TC002418 agreement area. AAPG Bulletin 49, 2182-2245.

Jolivet, L., Faccenna, C., 2000. Mediterranean extension and the Africa-Eurasia collision. Tectonics 19, 1095-1106.

Jordan, C.F., Connally, T.C., Vest, H.A., 1985. Middle Cretaceous carbonates of the Mishrif 
634 Kent, P. E., 1979. The emergent Hormuz salt plugs of southern Iran. Journal of Petroleum 635 Geology 2, 117-144.

636 Khadivi, S., Mouthereau, F., Barbarand, J., Adatte, T., Lacombe, O., 2012. Constraints on 637 paleodrainage evolution induced by uplift and exhumation on the southern flank of the 638 Zagros-Iranian Plateau. Journal of the Geological Society of London 169, 83-97.

639 Kirkham, A., Bin Joma, M., Mckean, T. A. M., Palmer, A. F., Smith, M. J., Thomas, H., 640 Twombley, B., 1996. Fluid saturation prediction in a transition zone. GeoArabia 1(4), 551641566.

642 Koop, W., Stoneley, R., 1982. Subsidence history of the Middle East Zagros basin, Permian 643 to Recent. Philosophical Transactions of the Royal Society of London 305, 149-168.

644 Koperna, G. J., Melzer, L. S., Kuuskraa, V. A., 2006. Recovery of oil resources from the 645 residual and transitional oil zones of the Permian Basin. Society of Petroleum Engineers, 646 102972.

647 Lacombe, O., Bellahsen, N., Mouthereau, F., 2011. Fracture patterns in the Zagros Simply 648 Folded Belt (Fars, Iran): Constraints on early collisional tectonic history and role of basement 649 faults. Geological Magazine 148, 940-963. doi:10.1017/S001675681100029X

650 Lacombe, O., Mouthereau, F., Kargar, S., Meyer, B., 2006. Late Cenozoic and modern stress 651 fields in the western Fars (Iran): Implications for the tectonic and kinematic evolution of 652 central Zagros. Tectonics 25, TC1003. doi:10.1029/2005TC001831

653 Leroy, S., Gente, P., Fournier, M., D’acremont, E., Patriat, P., Beslier, M. O., Bellahsen, N., 654 Maia, M., Blais, A., Perrot, J., Al-Kathiri, A., Merkouriev, S., Fleury, J. M., Ruellan, P. Y., 655 Lepvrier, C., Huchon, P., 2004. From rifting to spreading in the eastern Gulf of Aden: A 
geophysical survey of a young oceanic basin from margin to margin. Terra Nova 16(4), 185-

657 192.

Mcphee, C., Reed, J., Zubizarreta, I., 2015. Core Analysis: A Best Practice Guide. Developments in Petroleum Science 64.

Mcquarrie, N., 2004. Crustal scale geometry of the Zagros fold-thrust belt, Iran. Journal of 661 Structural Geology 26, 519-535.

662

Mcquarrie, N., Stock, J. M., Verdel, C., Wernicke, B. P., 2003. Cenozoic evolution of 663 Neotethys and implications for the causes of plate motions. Geophysical Research Letters 30. doi:10.1029/2003GL017992

Melzer, L. S., Kuuskraa, V. A., Koperna, G. J., 2006. The Origin and Resource Potential of 666 Residual Oil Zones. Society of Petroleum Engineers, 102964.

667 Miall, A., 2010. Principles of Sedimentary Basin Analysis. Springer-Verlag, New York.

Mina, P., Razaghnia, M. T., Paran, Y., 1967. Geological and geophysical studies and 669 exploratory drilling of the Iranian continental shelf-Persian Gulf. Proceedings of the Seventh 670 World Petroleum Congress, Mexico 2, 771-903.

671 Mohajjel, M., Fergusson, C. L., 2000. Dextral transpression in Late Cretaceous continental 672 collision, Sanandaj-Sirjan Zone, western Iran. Journal of Structural Geology 22, 1125-1139.

673 Molinaro, M., Leturmy, P., Guezou, J. C., Frizon de Lamotte, D., Eshraghi, S. A., 2005. The 674 structure and kinematics of the south-eastern Zagros fold-thrust belt; Iran: From thin-skinned 675 to thick-skinned tectonics. Tectonics 24. 10.1029/2004TC001633. 
676 Morris, P., 1977. Basement structure as suggested by aeromagnetic surveys in southwest Iran.

677 Internal report of National Iranian Oil Company.

678 Motiei, H., 1995. Petroleum Geology of Zagros. In: Hushmandzadeh, A. (ed.), Treatise on the 679 Geology of Iran. Geological Survey of Iran, Iran.

680 Mouthereau, F., 2011. Timing of uplift in the Zagros belt/Iranian plateau and accommodation 681 of late Cenozoic Arabia-Eurasia convergence. Geological Magazine 148, 726-738.

682 Mouthereau, F., Lacombe, O., Verges, J., 2012. Building the Zagros collisional orogen: 683 Timing, strain distribution and the dynamics of Arabia/Eurasia plate convergence. 684 Tectonophysics. s 532-535. 27-60. 10.1016/j.tecto.2012.01.022.

685 Mouthereau, F., Tensi, J., Bellahsen, N., Lacombe, O., De Boisgrollier, T., Kargar, S., 2007. 686 Tertiary sequence of deformation 26, TC5006. doi: 10.1029in a thin-skinned/thick-skinned 687 collision belt: The Zagros Folded Belt (Fars, Iran). Tectonics /2007TC002098

688 Murris, R. J., 1980. Middle East: Stratigraphic evolution and oil habitant. Geologie en 689 Mijnbouw 60, 467-486.

690 O'sullivan, T., Praveer, K., Shanley, K., Dolson, J. C., Woodhouse, R., 2010. Residual 691 hydrocarbons-a trap for the unwary. Society of Petroleum Engineers 128013.

692 Parker, A. R., Rudd, J. M., 2000. Understanding and Modelling Water Free Production In 693 Transition Zones. Society of Petroleul Engineers 59412.

694 Pelissier, J., Hedayati, A. A., Abgrall, E., Plique, J., 1980. Study of Hydrodynamic Activity 695 in the Mishrif Fields, Offshore Iran. Society of Petroleum Engineers. doi:10.2118/7508-PA. 
696 Pirouz, M., Simpson, G., Bahroudi, A., Azhdari, A., 2011. Neogene sediments and modern 697 depositional environments of the Zagros foreland basin system. Geological Magazine 148, $698 \quad 838-853$.

699 Purser, B., 1973. The Persian Gulf: Holocene carbonate sedimentation and diagenesis in a 700 shallow epicontinental sea. Springer-Verlag: Berlin and New York, pp. 157-177.

701

Robertson, A. H. F., 2000. Mesozoic-Tertiary tectonic sedimentary evolution of a south 702 Tethyan oceanic basin and its margins in southern Turkey. Geological Society of London, 703 Special Publication 173, 97-138.

704

Sengör, A. M. C., Altiner, D., Cin, A., Ustaömer, T., Hsü, K. J., 1988. The origin and 705 assembly of the Tethyside orogenic collage at the expense of Gondwanaland. Geological 706 Society of London, Special Publication 37, 119-181.

707

Sepehr, M., Cosgrove, J. W., 2004. Structural framework of the Zagros Fold-Thrust Belt, 708 Iran. Marine and Petroleum Geology 21, 829-843.

709

Setudehnia, A., 1978. The Mesozoic sequence in south-west Iran and adjacent areas. Journal 710 of Petroleum Geology 1, 3-42.

711

Sharland, P.R., Archer, R., Casey, D.M., Davies, R.B., Hall, S.H., Heward, A.P., Horbury, 712 A.D., Simmons, M.D., 2001. Arabian Plate Sequence Stratigraphy. Geo Arabia Special 713 Publication 2, Gulf PetroLink, Bahrain, 371 p.

714 Sherkati, S., Letouzey, J., 2004. Variation of structural style and basin evolution in the central Zagros, Iran. Marine and Petroleum Geology 21(5), 535-554. 
717 New insights from seismic data, field observation and sandbox modelling. Tectonics 25, 718

Sherkati, S., Letouzey, J., Frizon de Lamotte, D., 2006. Central Zagros fold-thrust belt (Iran): TC4007. doi:10.1029/2004TC001766

Spinler, E. A., Baldwin, B. A., 1999. A direct method for determining complete positive and negative capillary pressure curves for reservoir rock using the centrifuge. AAPG Memoir 71, $175-178$.

Stampfli, G. M., Borel, G. D., 2002. A plate tectonic model for the Paleozoic and Mesozoic constrained by dynamic plate boundaries and restored synthetic oceanic isochrons. Earth and Planetary Science Letters 196, 17-33.

Stöcklin, J., 1968. Structural history and tectonics of Iran: A review. AAPG Bulletin 52, $1229-1258$.

Stocklin, J., 1974. Possible ancient continental margins in Iran. In: Burk, C. A. and Drake, C. L. (eds), The Geology of Continental Margins, pp. 873-887. Springer: Berlin.

Swift, S. A., Ross, D. A., 2002. Neogene Stratigraphic Development of the Persian Gulf, Defence Technical Information Centre.

Szabo, F., Kheradpir, A., 1978. Permian and Triassic stratigraphy, Zagros Basin, south-west Iran. Journal of Petroleum Geology 1, 57-82.

Tavani, S., Storti, F., Soleimany, B., Fallah, M., Munoz, J., Gambini, R., 2011. Geometry, kinematics and fracture pattern of the Bangestan anticline, Zagros, SW Iran. Geological Magazine 148, 964-979. 10.1017/S0016756811000197.

Thomasen, J. B., Jacobsen, N. L., 1994. Dipping Fluid Contacts in the Kraka Field, Danish North Sea. Society of Petroleum Engineers. doi:10.2118/28435-MS. 
738 Tiab, D., Donaldson, E. C., 2015. Petrophysics: Theory and practice of measuring reservoir 739 rock and fluid transport properties. Gulf Professional Publishing: Boston.

740 Uchupi, E., Swift, S. A., Ross D. A., 1999. Late Quaternary stratigraphy, paleoclimate and 741 neotectonism of the Persian (Arabian) Gulf region. Marine Geology 160, 1-2.

Vejbaek, O. V., Frykman, P., Nielsen, C. M., 2005. The history of the hydrocarbon filling of Danish chalk fields. Geological Society of London 6, 1331-1345.

Verdel, C., Wernicke, B. P., Hassanzadeh, J, Guest, B., 2011. A Paleogene extensional arc flare-up in Iran. Tectonics 30, TC3008.

Verges, J., Saura, E., Casciello, E., Fernàndez, M., Villasenor, A., Jimenez-Munt, I., GarciaCastellanos, D., 2011. Crustal-scale cross-sections across the NW Zagros belt: Implications for the Arabian margin reconstruction. Geological Magazine. 10.1017/S0016756811000331 Vincent, S. J., Allen, M. B., Ismail-Zadeh, A. D., Flecker, R., Foland, K. A., Simmons, M. D., 2005. Insights from the Talysh of Azerbaijan into the Paleogene evolution of the South Caspian region. GSA Bulletin 117, 1513-1533.

Yilmaz, Y., 1993. New evidence and model on the evolution of the southeast Anatolian orogen. GSA Bulletin 105, 251-271.

Ziegler, M. A., 2001. Late Permian to Holocene paleofacies evolution of the Arabian Plate and its hydrocarbon occurrences. GeoArabia 6, 445-504. 
Graphic Abstract: Presence of residual oil below the present-day FWL is related to the northeast downward tilting of the entire Persian Gulf foreland basin

Figure 1: Examples of the presence of residual oil below the FWL and OWC in three studied fields (A, B and C). Second track shows fliud content: green $=$ oil, blue =water. More residual oil below the FWL and OWC is seen in the northerrn parts of each field.

Figure 2: Cross plots of static formation pressure data vs depth (TVDSS). A) FWL at $2900 \mathrm{~m}$ TVDSS in field A and B) FWL at $2337 \mathrm{~m}$ TVDSS in field C.

771

Figure 3: Fluid contact (blue line) determination in wells drilled and logged prior to the start of production in studied fields. Field A presents a FWL obtained from the formation pressure data in a northern well. This FWL is supported by the same OWC depth determined from the $\log$ data in two southern and one northern wells. A paleo OWC is seen at $2942 \mathrm{~m}$ TVDSS.

Field B shows an OWC at $1221 \mathrm{~m}$ TVDSS from the data of 5 wells located in different parts of the field. There is no formation pressure data in this field.

Field C illustrates a FWL at 2337 m TVDSS determined from the extrapolation of formation pressure data in a well located in the south of the field. Depth of this FWL is supported by ODT and WUT seen in a well drilled on the northern flank of the field.

Figure 4: Summary of regional geology in the area.

Figure 5: Sedimentation in the Persian Gulf foreland basin from the late Turonian to the

787 Figure 6: Movement of the Persian Gulf forebulge toward the orogenic suture making the 788 Persian Gulf narrower after Mid Miocene. Locations of field B before and after tectonic 
791

792

793

794

795

796

797

798

799

800

801

802

803

804

805

806

807

808

809

810

811

812

813

814

815

816

817

818

819 820

subsidence is shown with dash and solid rectangles respectively. This exerted a northward tilting on the entire basin.

Figure 7: Sedimentation in the narrower and northwardly tilted Persian Gulf foreland basin from the Mid Miocene to the present. Location of field B on the basin (Sarvak Fm is the reservoir) is shown with rectangle.

Figure 8: The most important processes of forming ROZ prior to the start of reservoir production. A: leakage in the seal and cap rock, B: hydrodynamic and active aquifer, $\mathrm{C}$ : regional tilting.

Figure 9: Effect of basin tilting on FWL and OWC adjustment and and changing capillary pressure regimes across the field A,

A: Before Mid Miocene, regions 1 and 5 were located below the fluid contact and other areas (2, 3 and 4$)$ were above the fluid contact.

B: After Mid Miocene, regions 1, 2, 4 and 5 were located below the fluid contact and area 3 were above the fluid contact. Early accumulated oil in regions 2 and 4 was displaced by water and residual oil was trapped below the new fluid contact.

Figure 10: Petrophysical evaluation of A6 showing a FWL at 2900 TVDSS. There is a thickness of residual oil zone and oil staining below this FWL.

Figure 11: Petrophysical evaluation of well A4. This well was drilled on the northern flank of field A beyond the FWL (2900 m TVDSS). Top Sarvak (Mishrif) is located $12 \mathrm{~m}$ below the present day FWL. 30\% residual oil below the field FWL and OWC disappears at 2942 showing a paleo fluid contact.

Figure 12: A: Long regional seismic section $(140 \mathrm{~km})$ crossing field A illustrates asymmetric and wedge-shaped Persian Gulf foreland basin. The Mid Miocene horizon shows a $2050 \mathrm{~m}$ flexural load over $140 \mathrm{~km}$ suggesting a tilt of 0.836 degrees for the Persian Gulf foreland basin.

B: Acoustic Impedance section through Field B emphasises same northwardly tilting. 
821 Figure 13: Thickness comparison and structural growth in one of the studied fields following 822 deposition of the Sarvak (Mishriff) Fm reservoir. Both plots (A and B) show an increase in 823 the thickness of formations deposited after the Miocene (Guri, Gachsaran, Mishan, Aghajari 824 and Bakhtiyari Formations) in the northern wells (A4 and A6) compared to central (A2) and 825 southern wells (A5 and A38). This is related to additional tilting toward N and NW which 826 was superimposed to the entire basin after Mid Miocene.

827

828

829 
- Residual oil occurs below the current fluid contact in many Middle Eastern reservoirs.

- This is related to tilting of the Arabian Plate towards the Zagros mountains.

- Tilting changed the equilibrium of the reservoirs and their fluid contents.

- Water partly replaced oil at the base of reservoirs creating residual oil zones. 


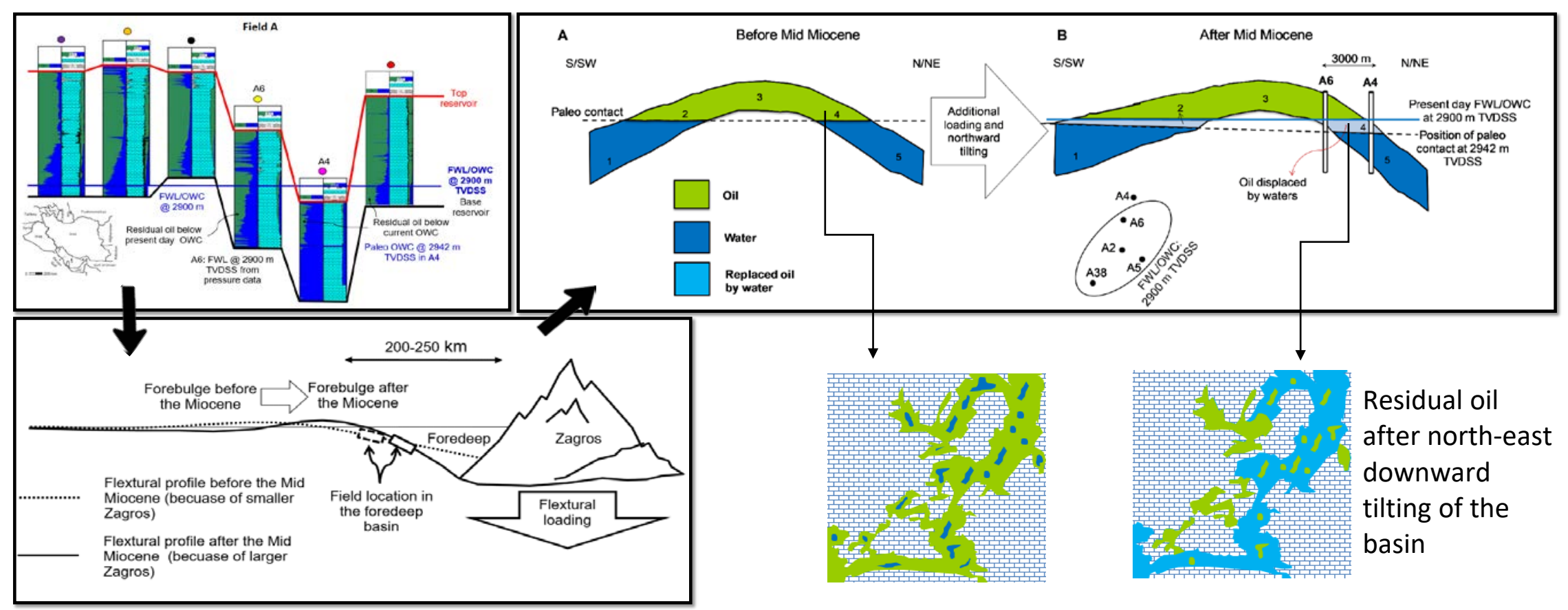




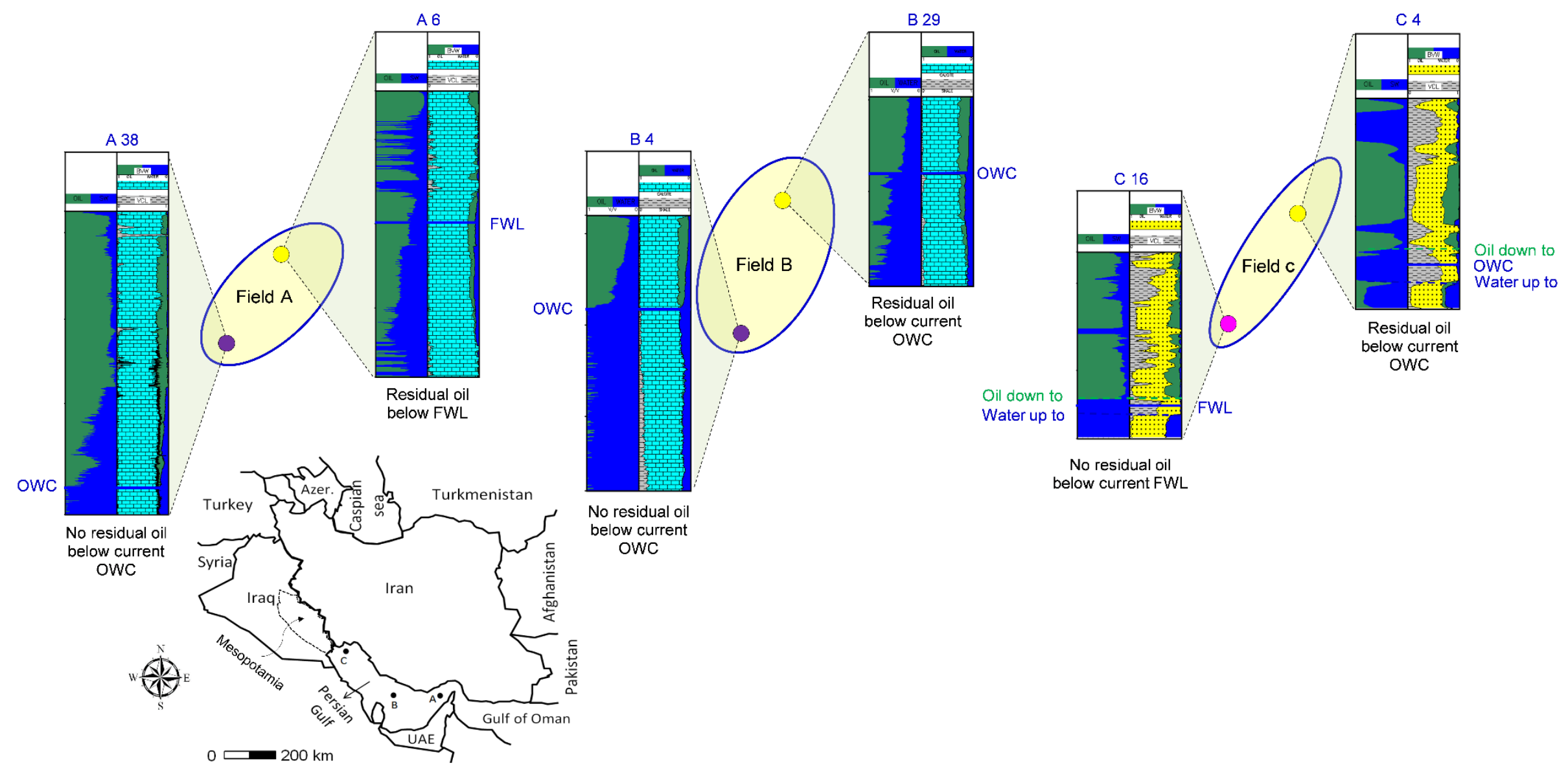

Figure 1: Examples of the presence of residual oil below the FWL and OWC in three studied fields (A, B and C). Second track shows fliud content: green $=$ oil, blue $=$ water. More residual oil below the FWL and OWC is seen in the northerrn parts of each field. 

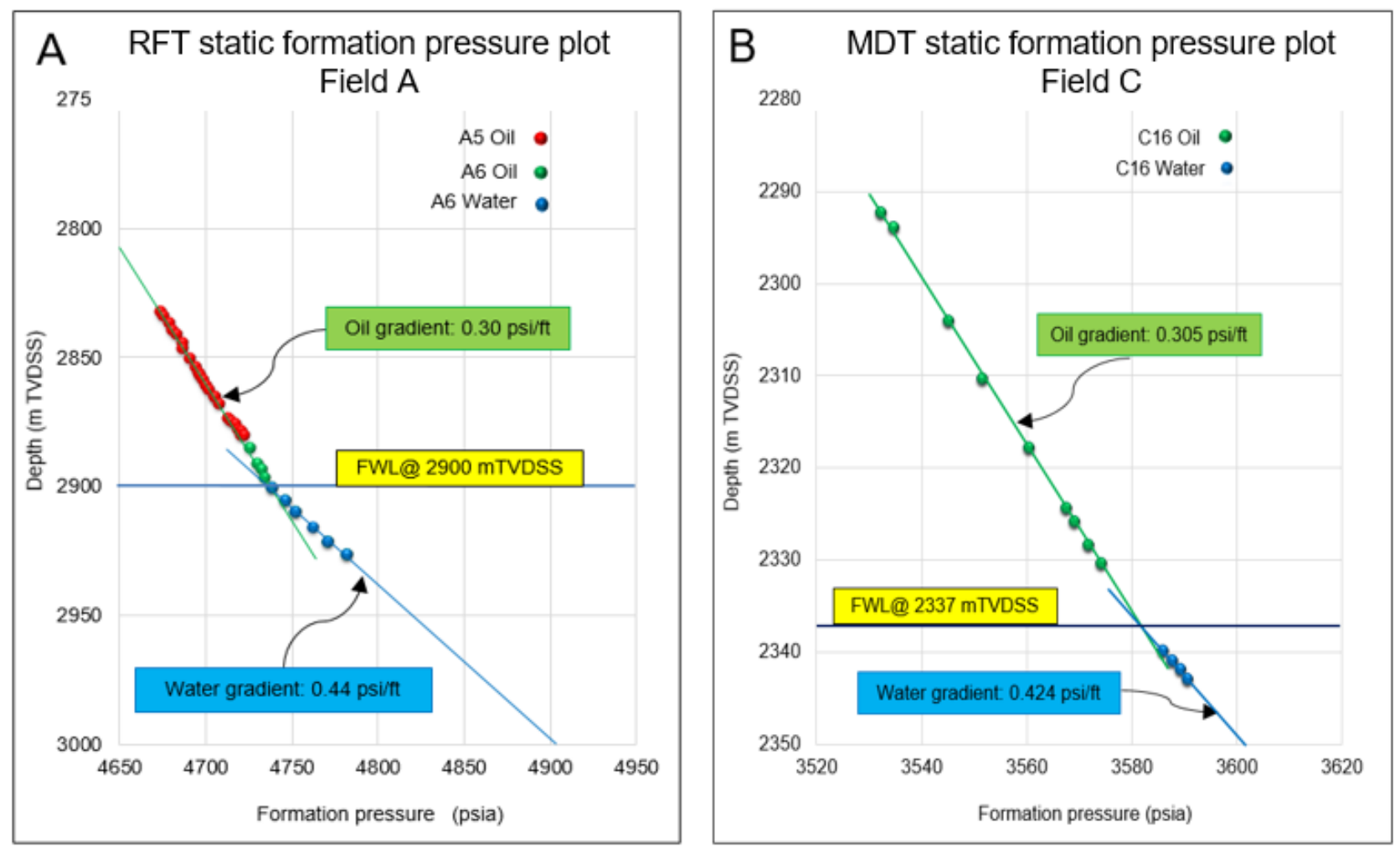

Figure 2: Cross plots of static formation pressure data vs depth (TVDSS). A) FWL at $2900 \mathrm{~m}$ TVDSS in field A and B) FWL at $2337 \mathrm{~m}$ TVDSS in field $\mathrm{C}$. 

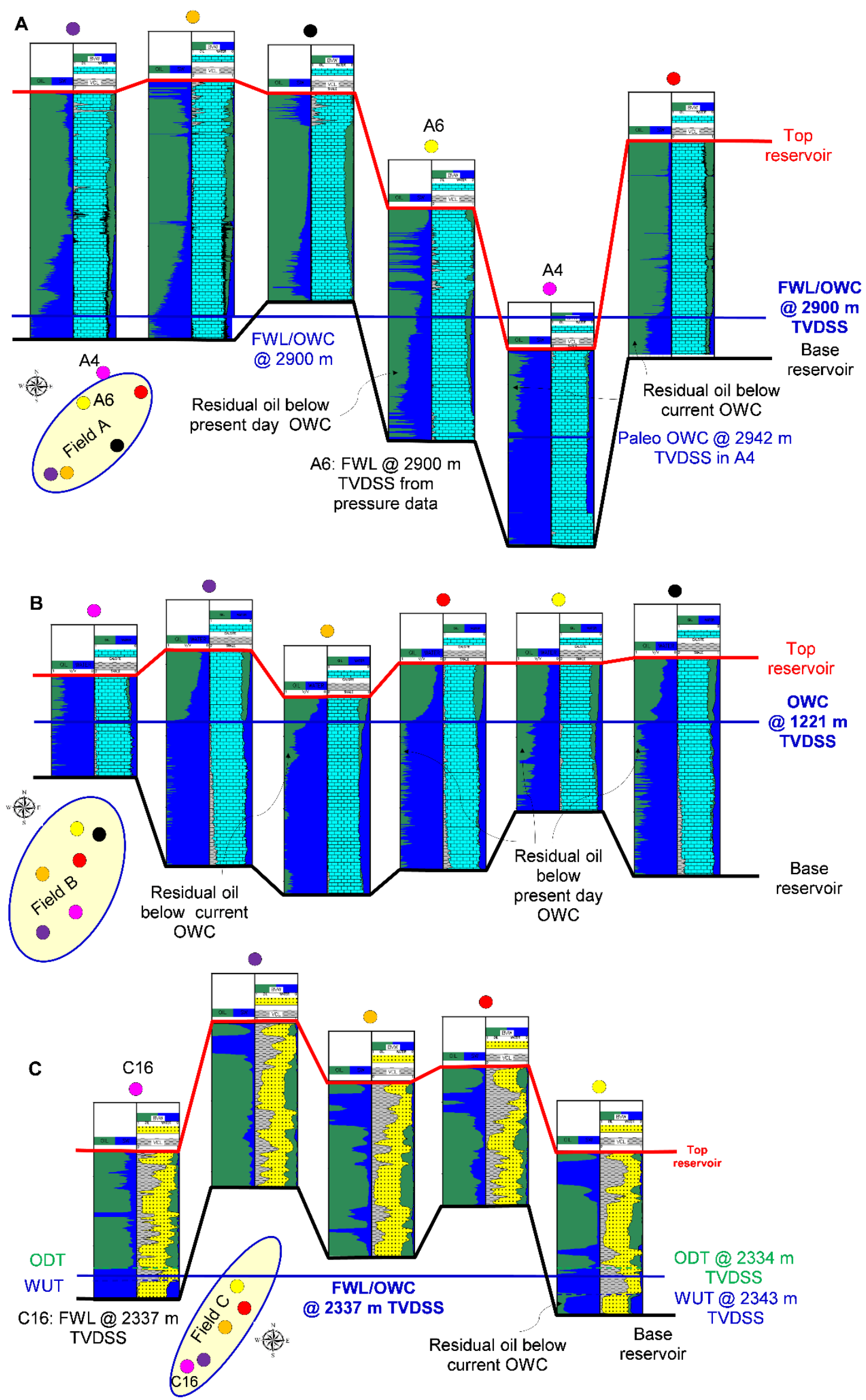
Figure 3: Fluid contact (blue line) determination in wells drilled and logged prior to the start of production in studied fields. Field A presents a FWL obtained from the formation pressure data in a northern well. This FWL is supported by the same OWC depth determined from the log data in two southern and one northern wells. A paleo OWC is seen at $2942 \mathrm{~m}$ TVDSS.

Field B shows an OWC at $1221 \mathrm{~m}$ TVDSS from the data of 5 wells located in different parts of the field. There is no formation pressure data in this field.

Field C illustrates a FWL at $2337 \mathrm{~m}$ TVDSS determined from the extrapolation of formation pressure data in a well located in the south of the field. Depth of this FWL is supported by ODT and WUT seen in a well drilled on the northern flank of the field. 


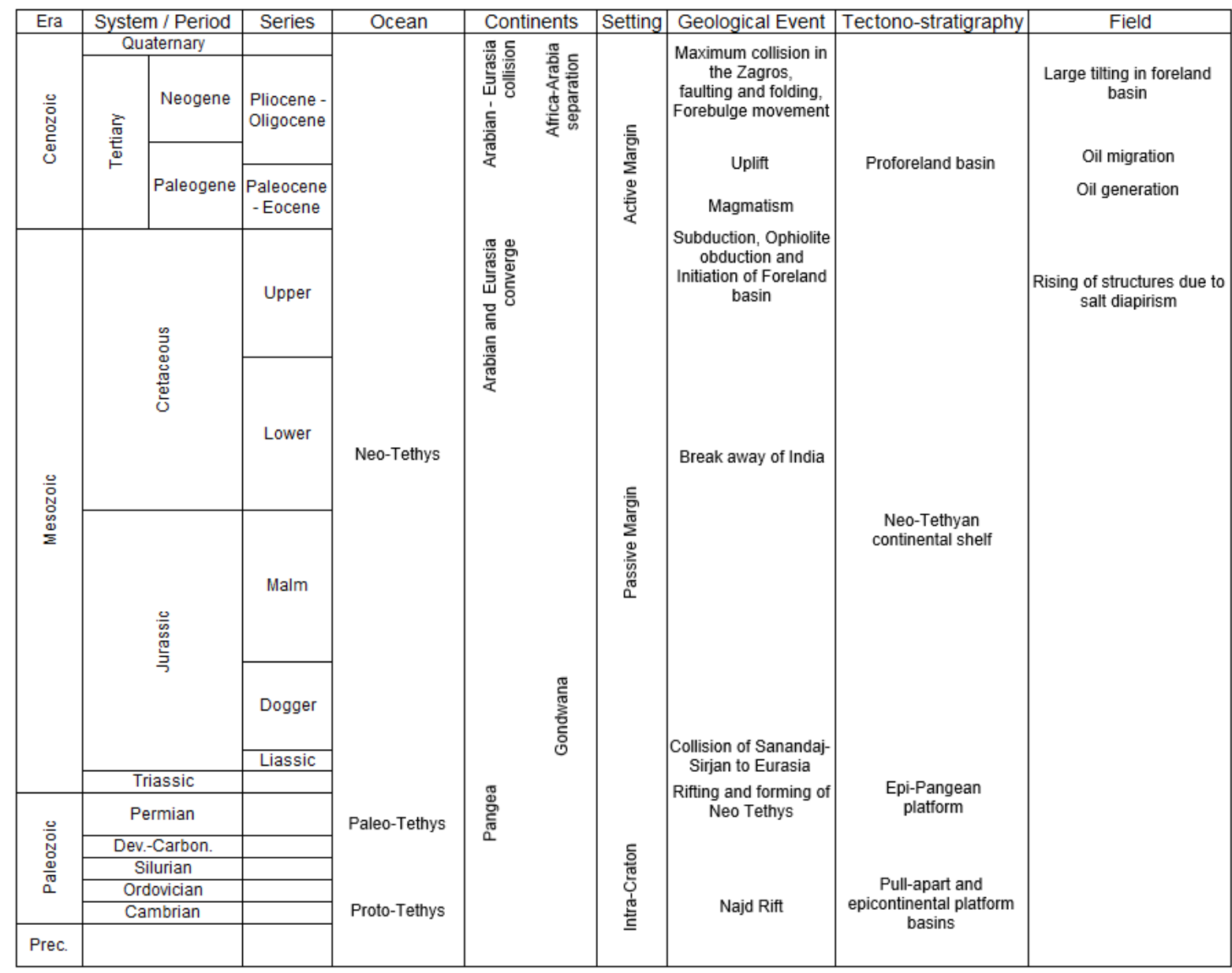

Figure 4: Summary of regional geology in the area. 


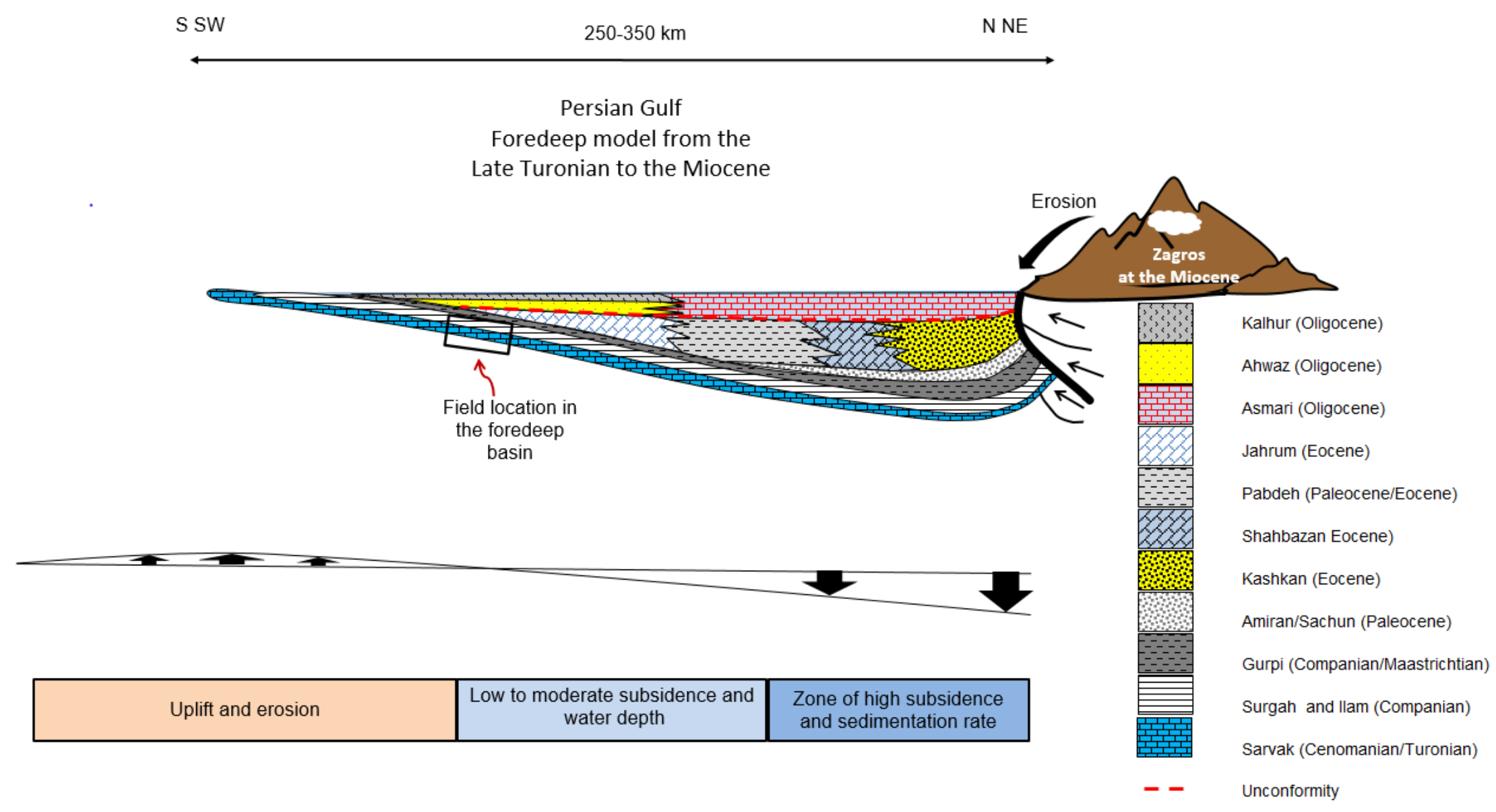

Figure 5: Sedimentation in the Persian Gulf foreland basin from the late Turonian to the Miocene. Location of field B on the basin is shown with rectangle. 


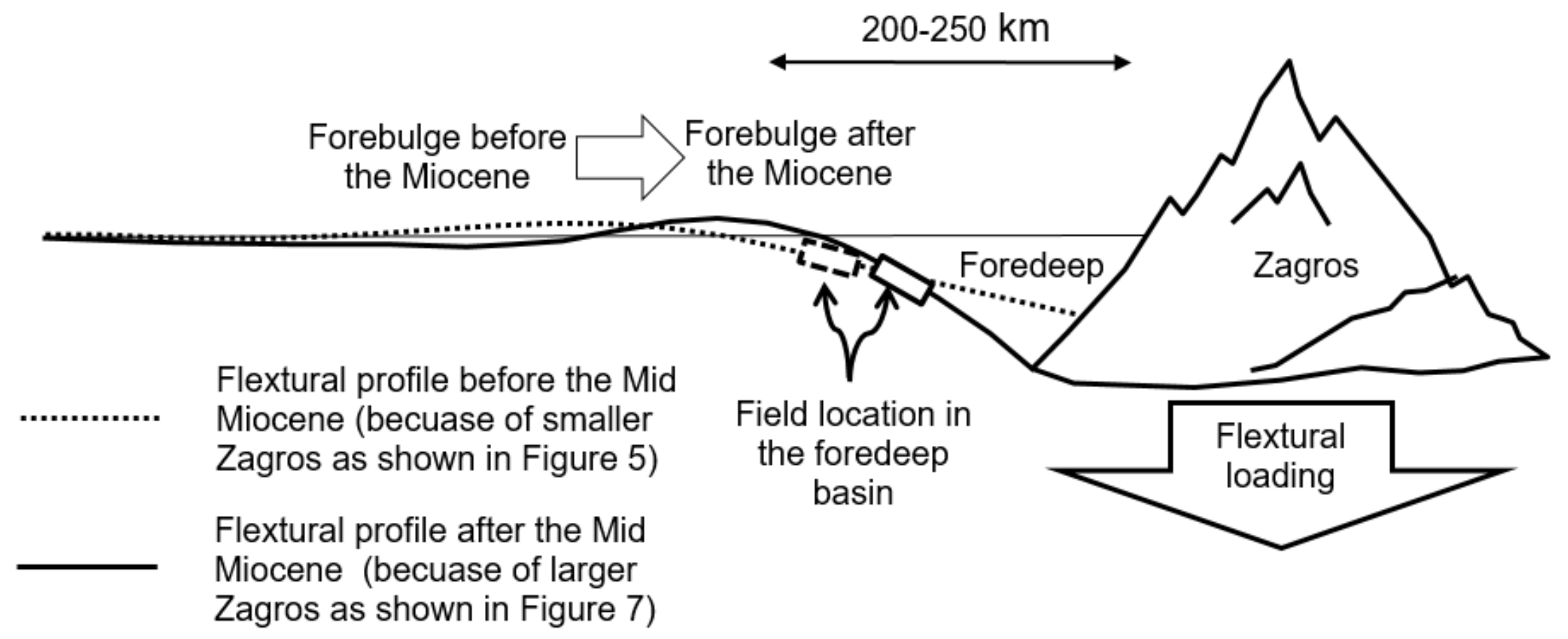

Figure 6: Movement of the Persian Gulf forebulge toward the orogenic suture making the Persian Gulf narrower after Mid Miocene. Locations of field $\mathrm{B}$ before and after tectonic subsidence is shown with dash and solid rectangles respectively. This exerted a northward tilting on the entire basin. 


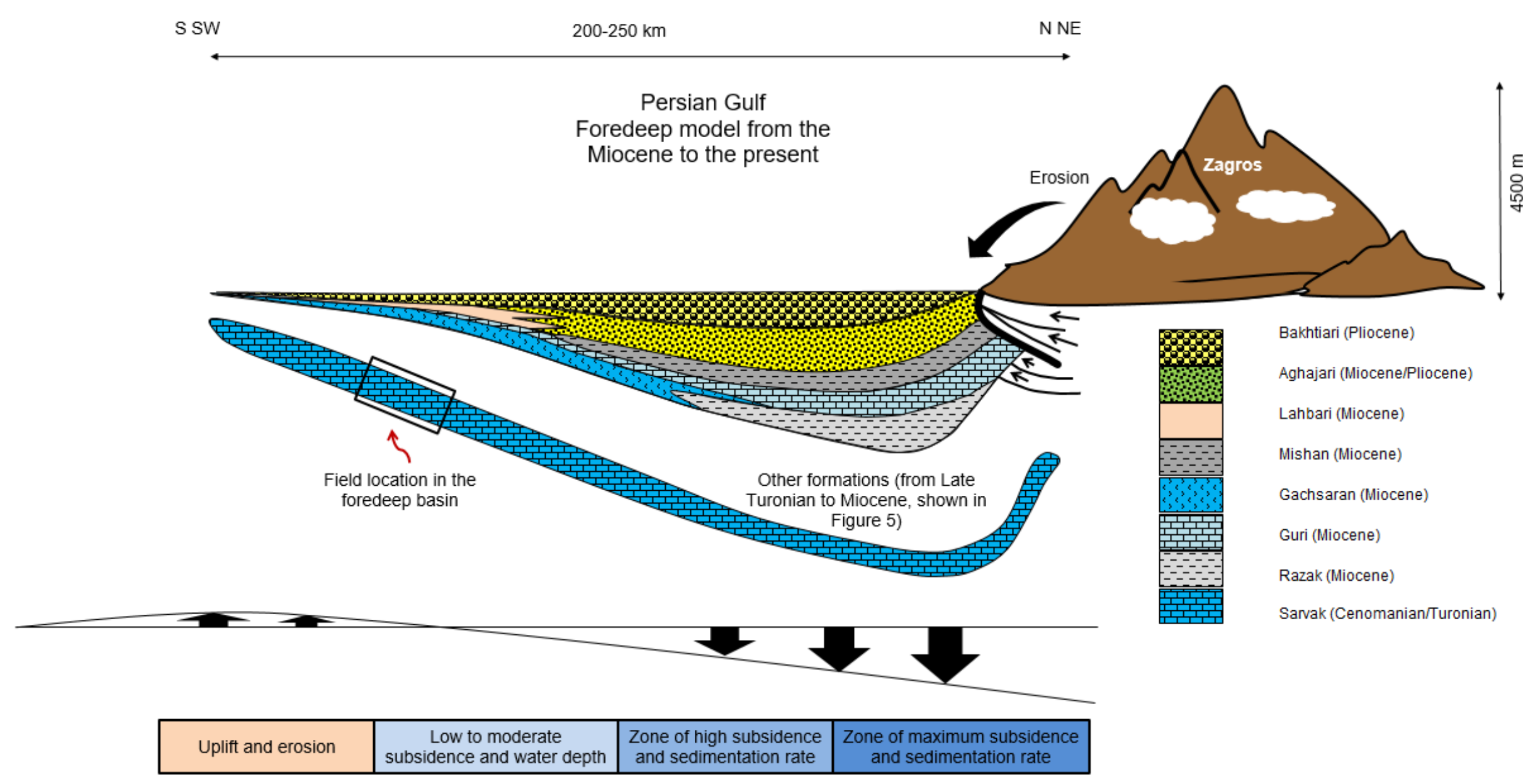

Figure 7: Sedimentation in the narrower and northwardly tilted Persian Gulf foreland basin from the Mid Miocene to the present. Location of field B on the basin (Sarvak Fm is the reservoir) is shown with rectangle. 


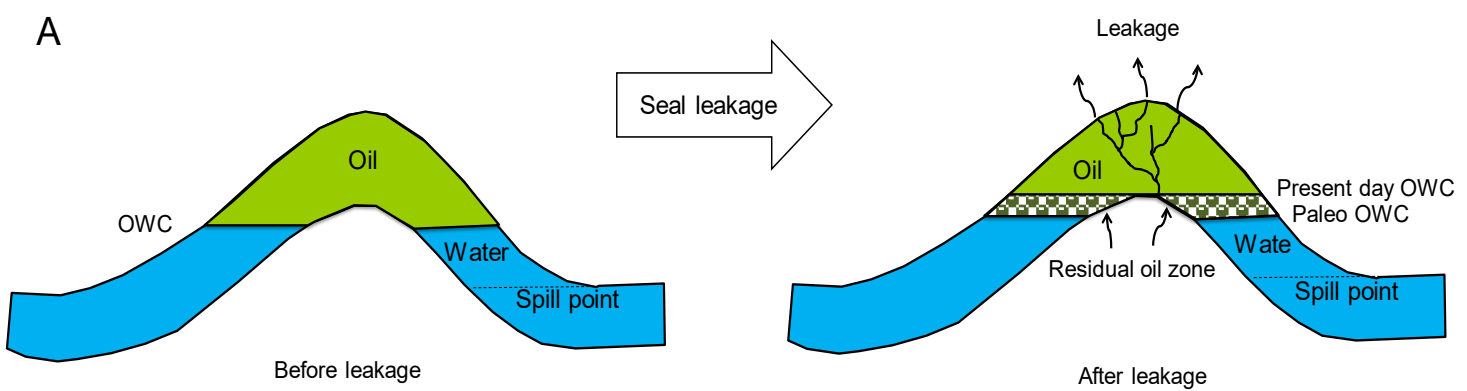

After leakage

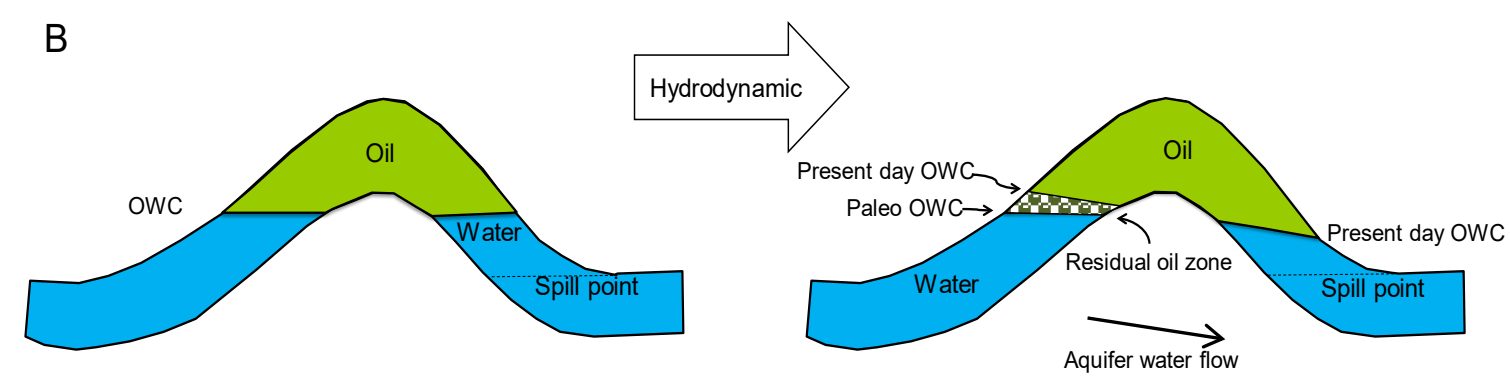

Before aquifer

After aquifer flow

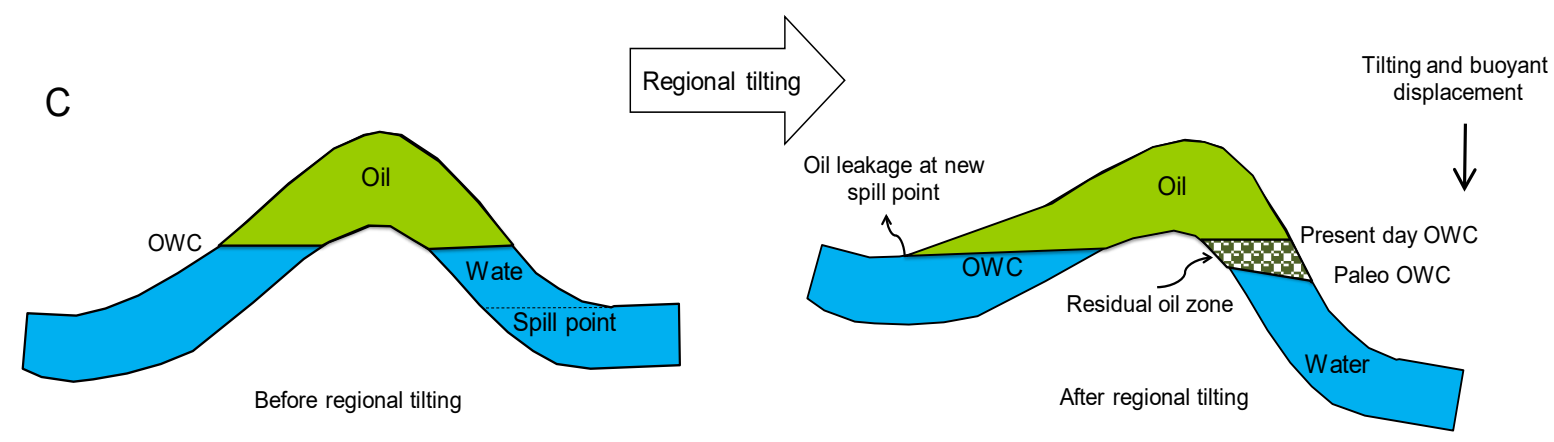

Figure 8: The most important processes of forming ROZ prior to the start of reservoir production. A: leakage in the seal and cap rock, B: hydrodynamic and active aquifer, C: regional tilting. 


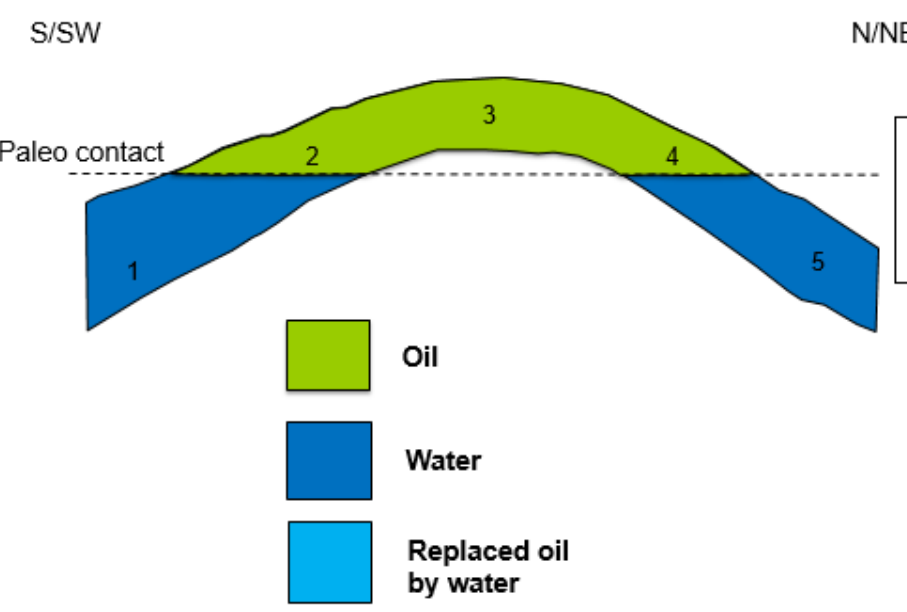

by water
B

S/SW
After Mid Miocene

SW $\stackrel{3000 \mathrm{~m}}{\longleftrightarrow} \mathrm{N} / \mathrm{NE}$

Additional loading and northward
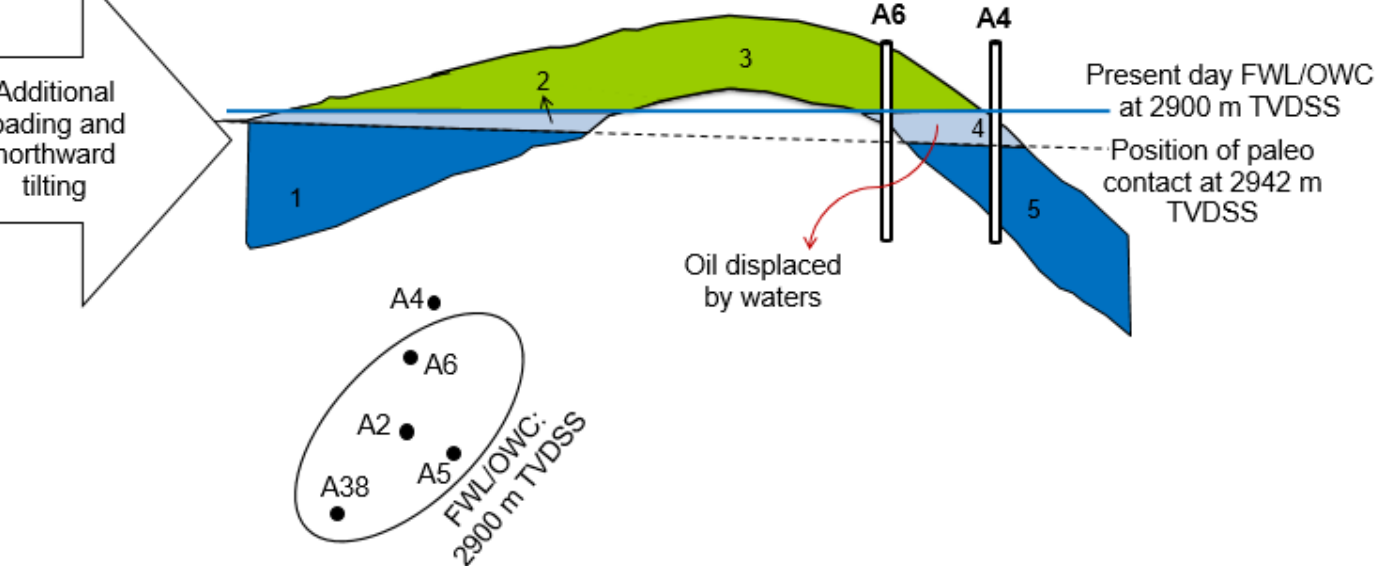
at $2900 \mathrm{~m}$ TVDSS

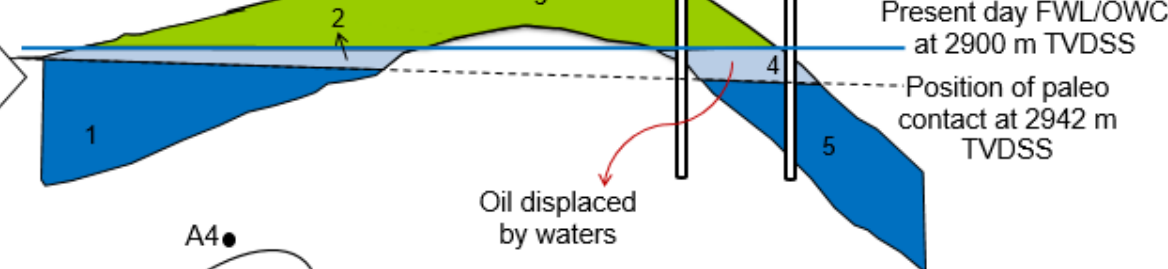

Figure 9: Effect of basin tilting on FWL and OWC adjustment and and changing capillary pressure regimes across the field A,

A: Before Mid Miocene, regions 1 and 5 were located below the fluid contact and other areas (2, 3 and 4$)$ were above the fluid contact.

B: After Mid Miocene, regions 1, 2, 4 and 5 were located below the fluid contact and area 3 were above the fluid contact. Early accumulated oil in regions 2 and 4 was displaced by water and residual oil was trapped below the new fluid contact. 


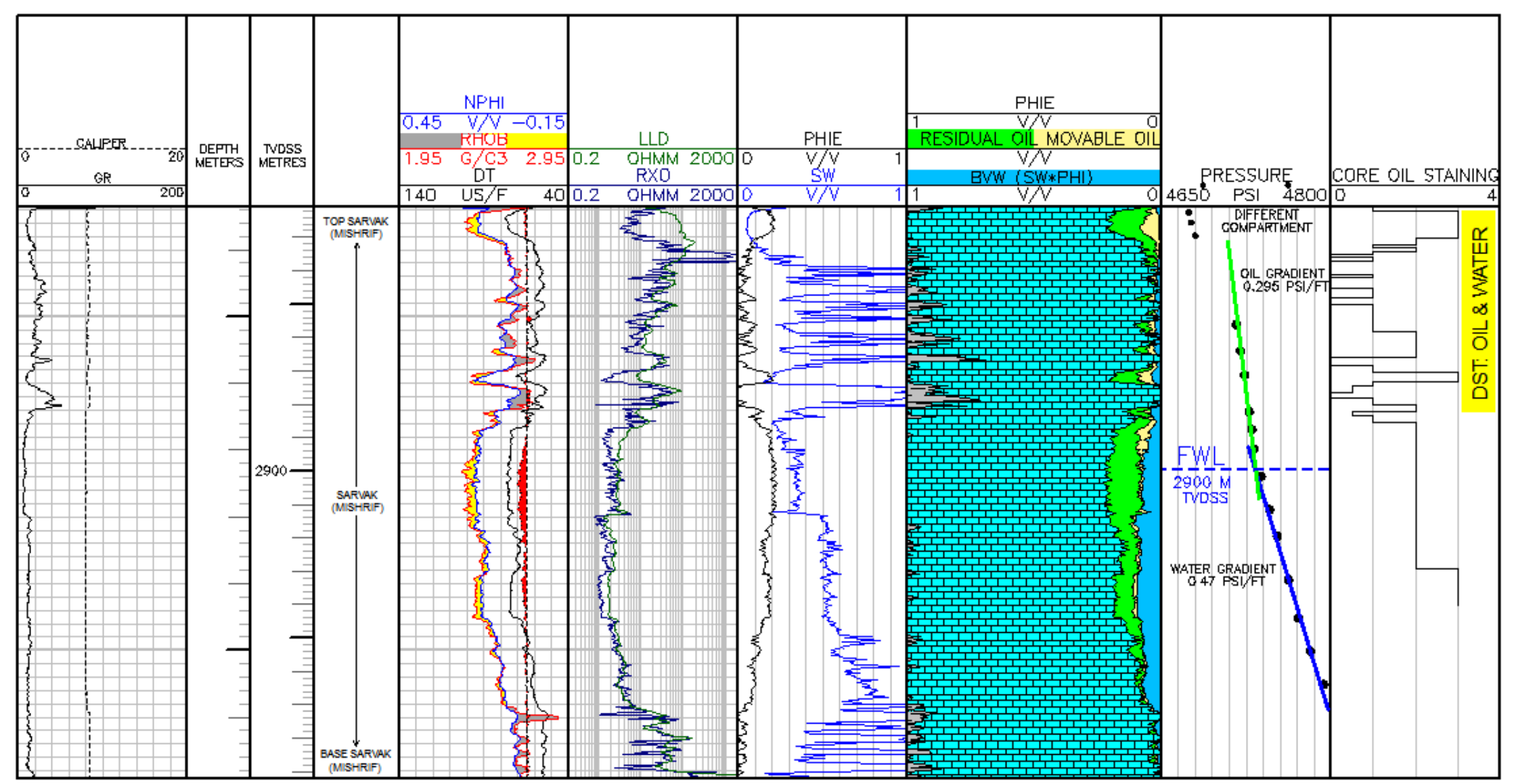

Figure 10: Petrophysical evaluation of A6 showing aWL at 2900 TVDSS. There is a thickness of residual oil zone and oil staining below this FWL. 


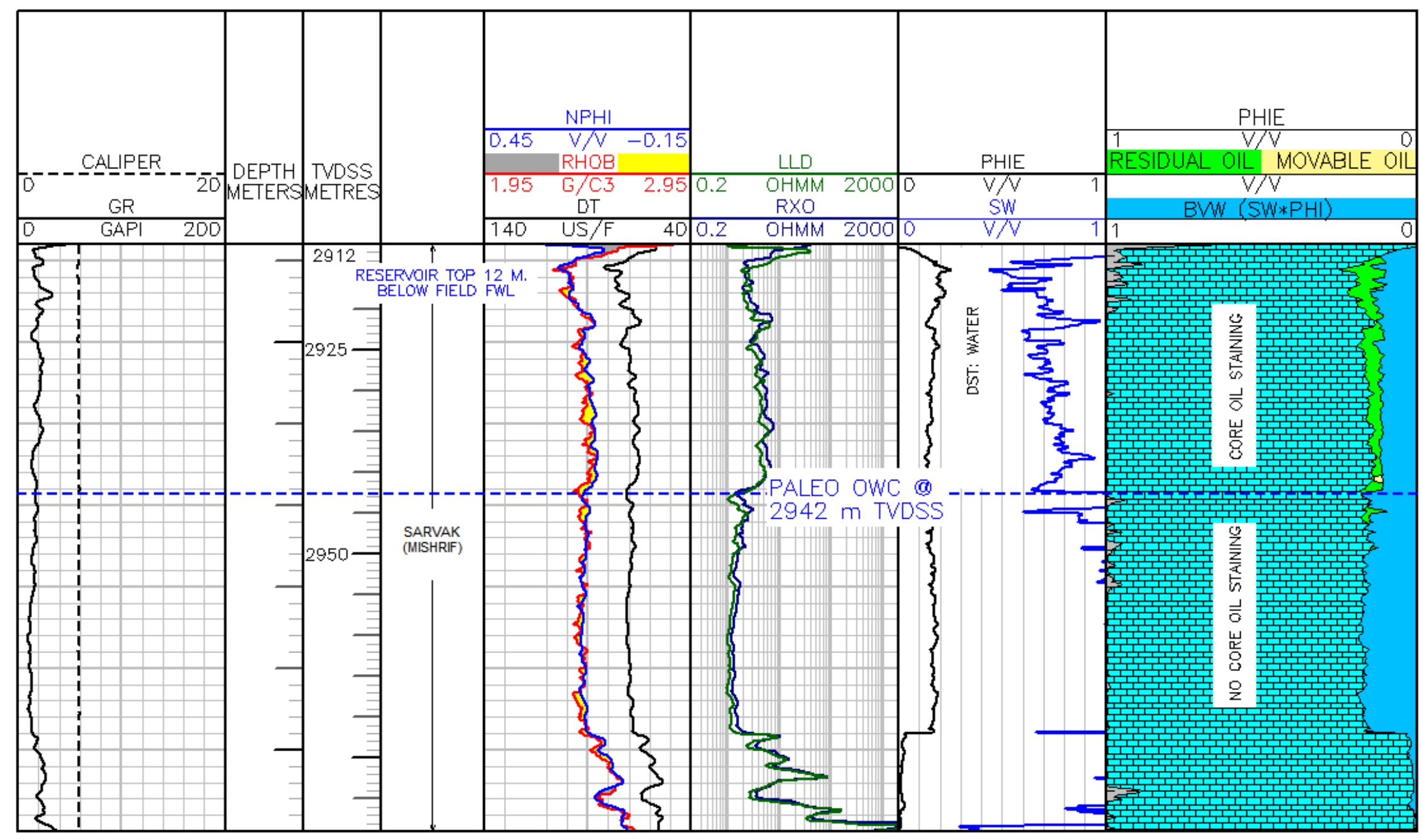

Figure 11: Petrophysical evaluation of well A4. This well was drilled on the northern flank of field A beyond the FWL (2900 m TVDSS). Top Sarvak (Mishrif) is located $12 \mathrm{~m}$ below the present day FWL. 30\% residual oil below the field FWL and OWC disappears at 2942 showing a paleo fluid contact. 

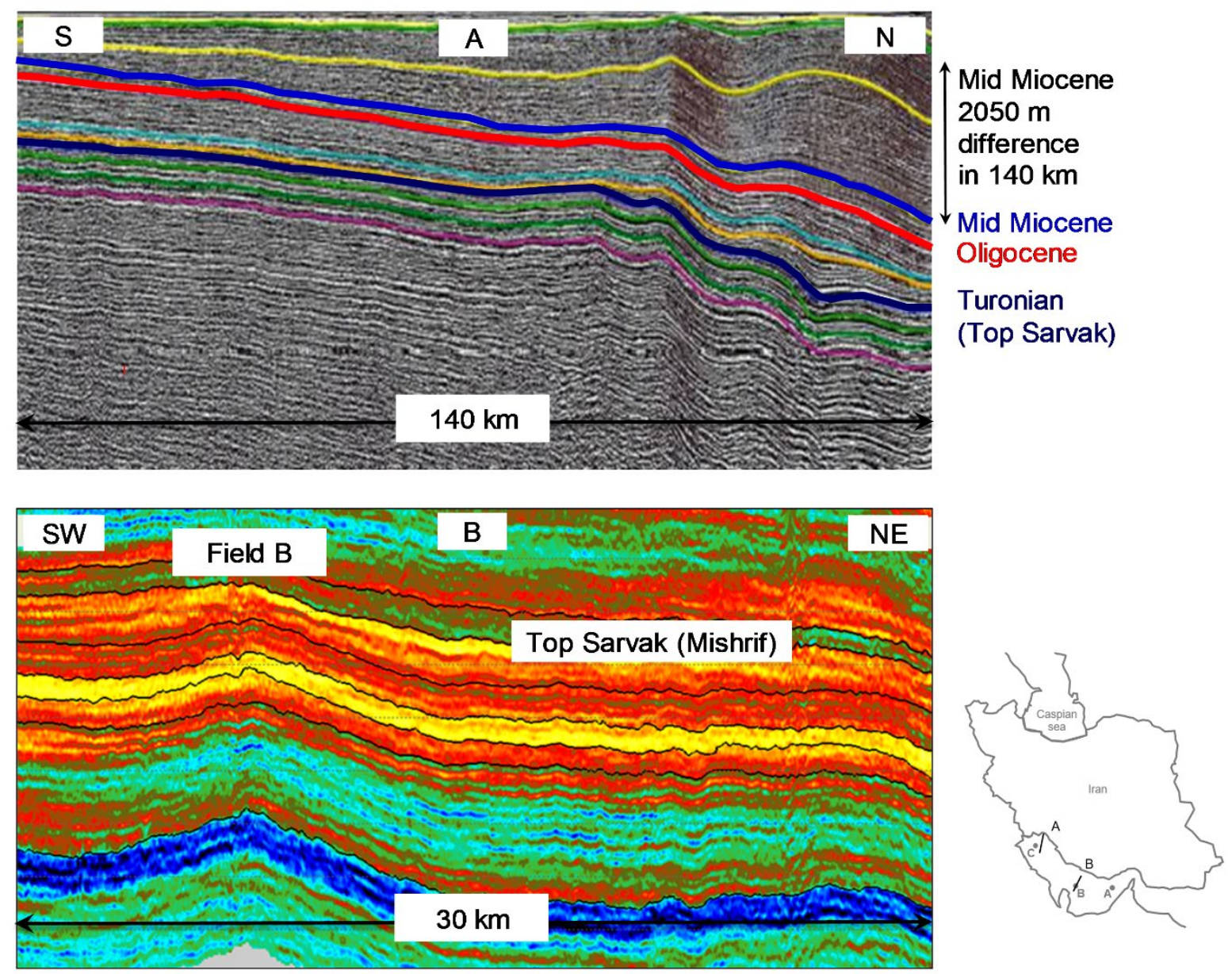

Figure 12: A: Long regional seismic section $(140 \mathrm{~km})$ crossing field A illustrates asymmetric and wedge-shaped Persian Gulf foreland basin. The Mid Miocene horizon shows a $2050 \mathrm{~m}$ flexural load over $140 \mathrm{~km}$ suggesting a tilt of 0.836 degrees for the Persian Gulf foreland basin.

B: Acoustic Impedance section through Field B emphasises same northwardly tilting. 


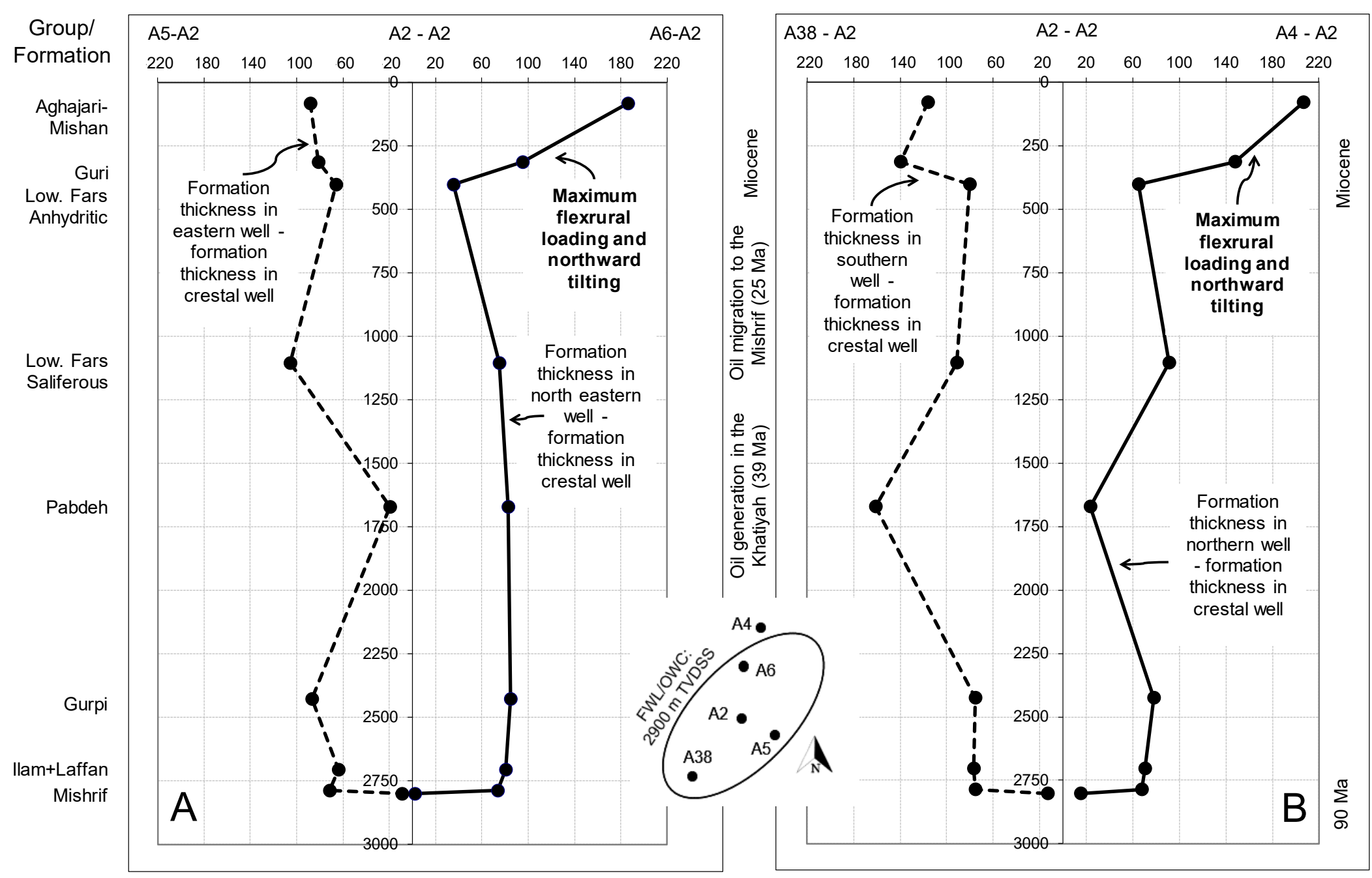

Figure 13: Thickness comparison and structural growth in one of the studied fields following deposition of the Sarvak (Mishriff) Fm reservoir. Both plots (A and B) show an increase in the thickness of formations deposited after the Miocene (Guri, Gachsaran, Mishan, Aghajari and 
Bakhtiyari Formations) in the northern wells (A4 and A6) compared to central (A2) and southern wells (A5 and A38). This is related to additional tilting toward $\mathrm{N}$ and NW which was superimposed to the entire basin after Mid Miocene. 
Graphic Abstract: Presence of residual oil below the present-day FWL is related to the northeast downward tilting of the entire Persian Gulf foreland basin

Figure 1: Examples of the presence of residual oil below the FWL and OWC in three studied fields (A, B and C). Second track shows fliud content: green $=$ oil, blue =water. More residual oil below the FWL and OWC is seen in the northerrn parts of each field.

Figure 2: Cross plots of static formation pressure data vs depth (TVDSS). A) FWL at $2900 \mathrm{~m}$ TVDSS in field A and B) FWL at $2337 \mathrm{~m}$ TVDSS in field C.

Figure 3: Fluid contact (blue line) determination in wells drilled and logged prior to the start of production in studied fields. Field A presents a FWL obtained from the formation pressure data in a northern well. This FWL is supported by the same OWC depth determined from the $\log$ data in two southern and one northern wells. A paleo OWC is seen at $2942 \mathrm{~m}$ TVDSS.

Field B shows an OWC at $1221 \mathrm{~m}$ TVDSS from the data of 5 wells located in different parts of the field. There is no formation pressure data in this field.

Field C illustrates a FWL at 2337 m TVDSS determined from the extrapolation of formation pressure data in a well located in the south of the field. Depth of this FWL is supported by ODT and WUT seen in a well drilled on the northern flank of the field.

Figure 4: Summary of regional geology in the area.

Figure 5: Sedimentation in the Persian Gulf foreland basin from the late Turonian to the Miocene. Location of field $\mathrm{B}$ on the basin is shown with rectangle.

Figure 6: Movement of the Persian Gulf forebulge toward the orogenic suture making the Persian Gulf narrower after Mid Miocene. Locations of field B before and after tectonic subsidence is shown with dash and solid rectangles respectively. This exerted a northward tilting on the entire basin.

Figure 7: Sedimentation in the narrower and northwardly tilted Persian Gulf foreland basin from the Mid Miocene to the present. Location of field B on the basin (Sarvak Fm is the reservoir) is shown with rectangle. 
Figure 8: The most important processes of forming ROZ prior to the start of reservoir production. A: leakage in the seal and cap rock, B: hydrodynamic and active aquifer, $\mathrm{C}$ : regional tilting.

Figure 9: Effect of basin tilting on FWL and OWC adjustment and and changing capillary pressure regimes across the field $\mathrm{A}$,

A: Before Mid Miocene, regions 1 and 5 were located below the fluid contact and other areas (2, 3 and 4) were above the fluid contact.

B: After Mid Miocene, regions 1, 2, 4 and 5 were located below the fluid contact and area 3 were above the fluid contact. Early accumulated oil in regions 2 and 4 was displaced by water and residual oil was trapped below the new fluid contact.

Figure 10: Petrophysical evaluation of A6 showing a FWL at 2900 TVDSS. There is a thickness of residual oil zone and oil staining below this FWL.

Figure 11: Petrophysical evaluation of well A4. This well was drilled on the northern flank of field A beyond the FWL (2900 m TVDSS). Top Sarvak (Mishrif) is located $12 \mathrm{~m}$ below the present day FWL. 30\% residual oil below the field FWL and OWC disappears at 2942 showing a paleo fluid contact.

Figure 12: A: Long regional seismic section $(140 \mathrm{~km})$ crossing field A illustrates asymmetric and wedge-shaped Persian Gulf foreland basin. The Mid Miocene horizon shows a $2050 \mathrm{~m}$ flexural load over $140 \mathrm{~km}$ suggesting a tilt of 0.836 degrees for the Persian Gulf foreland basin.

B: Acoustic Impedance section through Field B emphasises same northwardly tilting.

Figure 13: Thickness comparison and structural growth in one of the studied fields following deposition of the Sarvak (Mishriff) Fm reservoir. Both plots (A and B) show an increase in the thickness of formations deposited after the Miocene (Guri, Gachsaran, Mishan, Aghajari and Bakhtiyari Formations) in the northern wells (A4 and A6) compared to central (A2) and southern wells (A5 and A38). This is related to additional tilting toward $\mathrm{N}$ and NW which was superimposed to the entire basin after Mid Miocene. 
